\title{
Argentinos, bestias, chaqwa y pishtacos. La experiencia del terror, la crueldad y la muerte en la conciencia colectiva de los serranos en el periodo del conflicto interno en el Perú
}

\author{
Joanna Pietraszczyk-Sękowska \\ Departamento de Estudios Latinoamericanos y Comparativos, \\ Universidad de Łódź
}

\section{INTRODUCCIÓN}

La problemática del conflicto interno en el Perú es un tema de estudio difundido y ha sido analizado desde diversos ángulos científicos por investigadores nacionales y extranjeros durante casi cuatro décadas. ${ }^{1}$ Aparte de las interpretaciones predominantes en este tema, a saber, la histórica y política (centradas principalmente en las condiciones estructurales de la guerra y su impacto en la forma actual del Estado y la sociedad) y la antropológica (dedicada sobre todo a las fuentes y efectos socioculturales del problema), también ocupan un lugar significativo estudios sobre la violencia emprendidos en el marco de varias disciplinas. Sin embargo, el manejo de esta perspectiva es una tarea excepcionalmente compleja, porque, como si fuera a través de una lente, reúne sistemas de

\footnotetext{
${ }^{1}$ Entre la extensa literatura, deben mencionarse las monografías y estudios colectivos más importantes: Flores Galindo, Manrique 1986, Gorriti 1990, Degregori, Escobal, MartiCorena 1992, Degregori 1985, 1996a, 2003, 2013, Palmer 1994, Tapia 1997, Stern 1999, Manrique 2002, Śniadecka-Kotarska 2006, Rojas-Perez 2017, del Pino 2017, CVR 2008.
} 
vinculación de fenómenos y protagonistas, cuyos trazos no se pueden perfilar con nitidez. Esto se hace evidente, de modo particular, en las formas, escala y percepción del terror en los Andes.

El propósito del artículo es hallar respuesta a la pregunta sobre el papel que habrían desempeñado los terminos del título "terror, crueldad y muerte" en las acciones armadas en la provincia y cómo, en último término, habrían de influir en la conciencia colectiva de los aldeanos andinos y en sus posiciones frente al conflicto. Por lo tanto, el objeto del análisis se enfoca primordialmente en los aspectos reales de la violencia en los Andes y las formas de su visualización por parte de los serranos, así como en sus reacciones posteriores ante las experiencias bélicas de la deshumanización, la muerte y la destrucción.

Conforme a lo que reza el título, será el concepto de "conciencia social/colectiva" lo que determine las principales direcciones de análisis. En el texto lo uso práctiamente como sinónimo de "imaginario colectivo", aunque en la teoría científica el primero parece abarcar mucho más (como estados de conciencia y formas de percibir fenómenos), y el segundo, el "imaginario", se vería reducido a uno de los niveles de conciencia, aquel en el se engendran las representaciones de su contenido (definidas también en mi texto como "simbolizaciones" y "visualizaciones"). ${ }^{2}$ Utilizo todos estos conceptos de acuerdo con la tradición de Durkheim, aprovechando de su inclinación a establecer codependencia entre la percepción del individuo y el grupo, aun cuando yo veo esta última de una forma más antropológica, o sea, como una estructura sociocultural. En consecuencia, las reflexiones llevadas a cabo a lo largo del texto se asientan sobre el presupuesto básico de que las formas de percibir un trauma de larga duración y la violencia masiva, a pesar de gozar de dimensiones tanto individuales como grupales, siempre se remiten a fuentes sociales que emanan desde dentro de una comunidad cultural, también entendida como una comunidad de experiencias (en el caso de este estudio, se trata de la población andina del centro-sur del Perú, que acarreó con los mayores costes sociales en el conflicto). En otras palabras, los ejemplos individuales y colectivos de la representación de traumas surgen debido a la existencia de códigos comunes para la interpretación de la realidad y, posteriormente, para su simbolización. ${ }^{3}$

\footnotetext{
2 Véase: Marshall 2005: 379, 431, Lukes 2012: 17-19, Szacki 1981: 424.

3 Aunque al mismo tiempo no "substancializan" el espíritu colectivo, tan solo dan soporte a su idea. Para más información, véase: SzACKI 1981: 423-425 y LuKEs 2012: 17-22.
} 

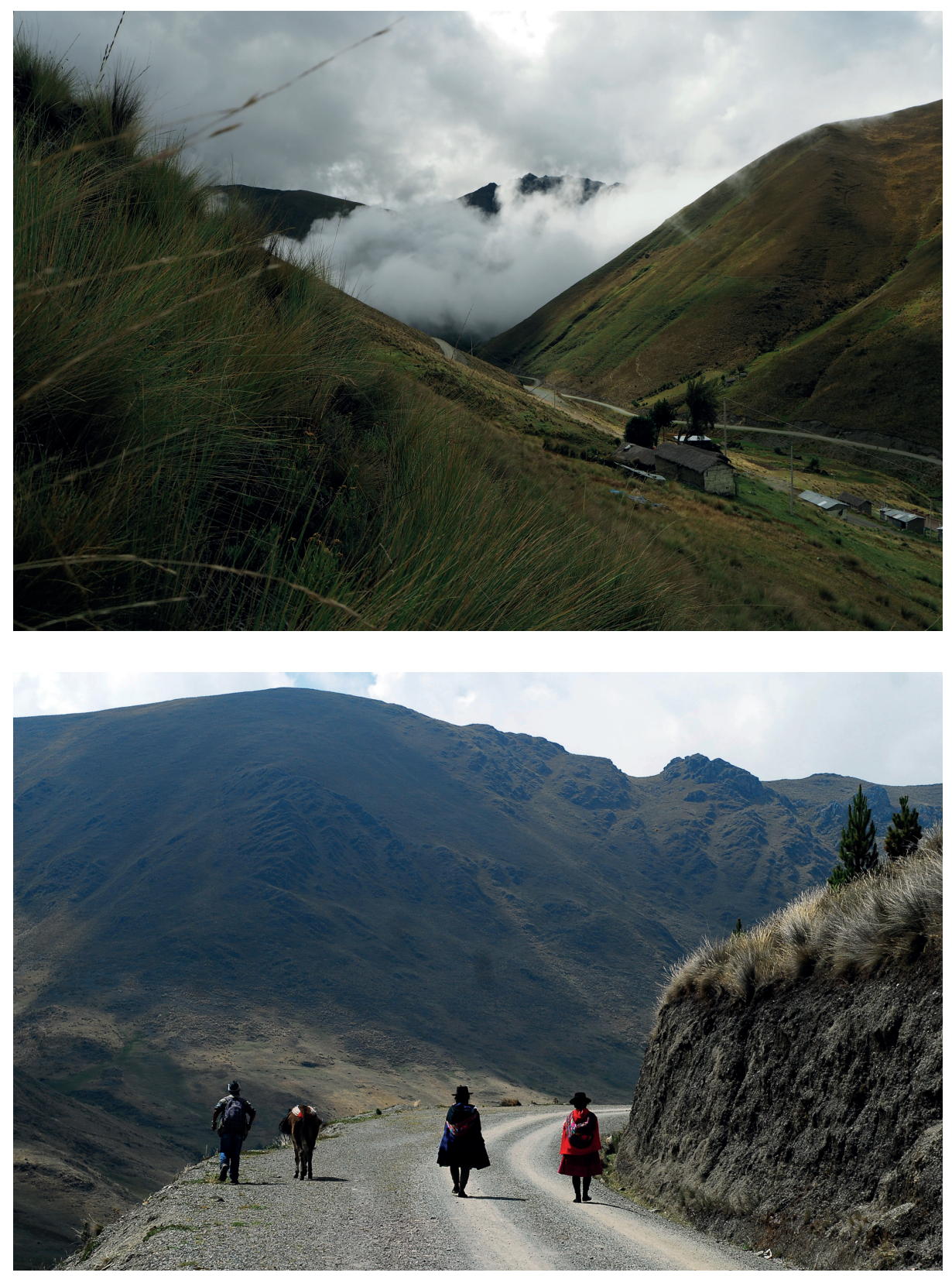

Figs. 1-2. Paisaje posbélico de las alturas de Huanta afectadas por el terror; zona Putis, octubre de 2015, fot. J. Pietraszczyk-Sękowska. 
Al mismo tiempo, tomo en consideración que, aun siendo los fenómenos estudiados inestables $y$, por ende, difíciles de aprehender, pueden analizarse tanto en relación con el cúmulo de teorías elaboradas, como del material de investigación, extenso y diverso. Por lo tanto, en el enfoque propuesto para el tema, en modo alguno reivindico el derecho exclusivo de interpretarlo. El punto de vista utilizado en el texto es sustancialmente angosto, y su marco se halla determinado en buena medida por los intereses de la antropología política, es decir, por los procesos de influencia del poder sobre grupos e individuos, así como por sus reproducciones realizadas desde las bases. ${ }^{4}$ En el terreno de la metodología, el artículo es un intento de cotejar la bibliografía, relativamente extensa, dedicada a las fuentes, formas e imágenes de violencia del período del conflicto interno peruano con los resultados de mi investigación en los Andes del centro-sur del Perú entre los años 2005-2010 y 2015-2019. ${ }^{5}$

\section{ACERCA DEL CONFLICTO POR EL IMPERIO DEL MIEDO}

El conflicto interno en Perú tuvo lugar entre los años 1980-2000 y su epicentro se encontraba en el terreno centro-sur de los Andes y en sus confines orientales. Fue iniciado por la organización clandestina maoísta Sendero Luminoso, que paulatinamente reforzaría su posición política en el departamento de Ayacucho y aledaños a lo largo de la década de los 70, hasta que en mayo de 1980 emprendiera su lucha armada contra el Estado. La reacción gubernamental frente a ello se reflejó en una intensificación de las intervenciones de fuerzas policiales y, tras dos largos años, en la transferencia del control de la zona de las actividades armadas al Ejército, así como al sometimiento no oficial, a esta misma institución, de los grupos campesinos de autodefensa que a la sazón empezaban a formarse. El objeto de rivalidad entre las partes en conflicto se centraba en el poder político, pero a resultas de las relaciones interétnicas profundamente desiguales desde el punto de vista histórico, las acciones militares contribuyeron a agilizar el mecanismo de la violencia cultural, lo que, en la provincia, no tardaría en conferirle un carácter de guerra civil. Entre sus primeras víctimas se contaría la población campesina de origen indígena, que en el intrincado juego de fuerzas cargaría con los mayores costes de la contienda, tanto a causa del uso de la fuerza y la intimidación, como mediante la hábil manipulación de los antagonismos regionales y locales. Ya en la primera mitad de los años 80, todo ello alcanzaría dimensiones destructivas en el plano social y psicocultural,

\footnotetext{
4 Véase: Lewellen 2010: 11-12 y DhaKal 2011.

5 Los viajes de investigación realizados en los años 2009/2010 y 2019 fueron financiados gracias a proyectos de MNiSzW (N N109 306837) y NCN (2018/02/X/HS5/00173).
} 
al igual que en el económico, generando así, y manteniéndolo durante su propio modelo del uso de la violencia en la provincia. Según este, tanto los militares como los senderistas y las fuerzas campesinas, consideraban la libre escala y forma de las perdidas entre los comuneros andinos como dentro de la lógica justificada de su lucha en el seno de este colectivo, supuestamente proclive a la manipulación y al cambio de actitudes en el conflicto. ${ }^{6}$

Por ende, este mecanismo conductor de la guerra civil, responsable a la par del profundo sentimiento de impotencia y desvalorizacion de la vida de los serranos y del predominio de la crueldad, la denuncia y la venganza como reguladores de las relaciones sociales, iba formando durante años al menos a tres generaciones de ayacuchanos. Una de las consecuencias de más largo alcance habría de ser el arraigo de la experiencia del temor, la muerte y la crueldad, en

${ }^{6}$ El área de conflicto, "institucionalizada" en octubre de 1981 como zona en estado de emergencia y entregada al control exclusivo de las fuerzas armadas catorce meses después, comprendía principalmente la provincia centro-sur del Perú, es decir, las áreas de los departamentos de Ayacucho y Huancavelica y una parte de Junín y Apurímac. Al inicio, los senderistas responsables del estallido de las acciones militares operaban de un modo claramente selectivo, como las fuerzas policiales a las que se enfrentaban (las segundas destacarían, sin duda alguna, por su nivel y formas de crueldad). Sin embargo, cuando las fuerzas armadas tomaron la zona a fines de 1982, el sadismo y la violencia masiva se convirtieron en una parte de la estrategia de pacificación de la provincia. La actitud del ejército comenzaría a cambiar a mediados de la década de 1980, cuando los métodos usados hasta entonces se revelaron como contraproducentes. Se consideraba como una de las soluciones el colaborar más estrechamente con las fuerzas campesinas de autodefensa, que sin embargo habían tenido (y seguían teniendo) una participación incuestionable en actos de terror contra los civiles. Aunque elementos de los fenómenos descritos también aparecerían en otras regiones del país, el material de investigación que yo presento y analizo concierne casi solo al departamento de Ayacucho (y, de forma fragmentaria, de Junín). No obstante, a mi juicio, esta propuesta no amenaza con una reducción significativa de las cuestiones apuntadas en el título, puesto que en la primera mitad de la década de 1980 las operaciones militares tuvieron lugar principalmente en Ayacucho, cuya población sufrió la gran mayoría (cerca de 100\%) de los costes sociales generados por la guerra durante este período (en este conflicto de 20 años, su contribución al total de víctimas mortales superó el $40 \%$, si a su vez tomamos en cuenta toda la region del centro y centro-sur del Perú, llegamos a un 85\% de las víctimas; CVR 2008: 433-434). Como ya he mencionado, con independencia de las etapas de la guerra y de sus actores, fue mayoritariamente la población campesina de origen indígena la gran víctima de la violencia, lo que se reflejaría claramente en las estadísticas de la Comisión de la Verdad y Reconciliación: de alrededor de los 70,000 muertos, el 80\% habitaba terrenos rurales y el 75\% eran campesinos cuya lengua materna no era el castellano; (véase: CVR 2008: 433-434 y COMISEDH 2012: 22, 72-82). Las comunidades andinas, cuyas experiencias y actitudes analizo en el texto, representan a la población campesina de origen indígena, con un gran apego a la tierra y fuerte sentimiento local, pero con un débil sentido de "indigenidad" (como proyecto político, véase: Posern-ZiELIŃSKi 2005 y 2008) . Es por eso que en el texto me refiero a ellos, de forma indistinta, como "población andina", "población campesina", "serranos", "comuneros" o simplemente "aldeanos" y "habitantes de las aldeas andinas". Si en raras veces aplico el termino de "indios", es porque así fueron llamados en el contexto estudiado. 
apariencia sin límites de tiempo y espacio, lo que determinaría las estrategias de adaptación de los andinos en el plano político-militar (sobre todo cálculo de las posibilidades de supervivencia y por consiguiente de las posibles "alianzas") y en el plano psicocultural (es decir, en lo referente a la condición psicoemocional y a sus consabidos frutos dentro del imaginario colectivo).

Si entramos en reflexión sobre las formas en que los serranos simbolizaron el terror, cabe formularse, con todo, una cuestión preliminar: la referida a las perspectivas de estudio realizadas sobre la percepción desde la base de los procesos de aniquilamiento de la provincia y sus habitantes. No obstante, a mi juicio, este asunto no debería ser analizado solo en referencia a los problemas surgidos en la relación senderistas-campesinos y militares-campesinos como fenómenos separados entre sí, puesto que limitaría la problemática mucho más compleja de las experiencias bélicas del miedo y la violencia habidas entre la población andina. El mecanismo, más arriba mencionado, de la recíproca escalada de terror por parte de senderistas, fuerzas gubernamentales y comités campesinos, estimulado por la rivalidad en cuanto al control sobre la provincia, parece mucho más simple de analizar para un investigador, que para los participantes en los sucesos, cuya gran mayoría fueron objetos y no sujetos de las acciones armadas y entre los cuales una parte significativa no se orientaba en la morfología de las mismas. Así pues, desde la perspectiva de la población aldeana, presa del espanto y en medio de los protagonistas del conflicto, la nitidez de los límites entre agresores se desvanecía con frecuencia, al igual que entre las causas y las consecuencias de sus actos devastadores. De ahí que, aun cuando algunas historias concretas de los aldeanos parecen estructuralmente bien modeladas, las formas en la descripción de la violencia sufrida por ellos suelen ya perder en lógica y claridad. El conflicto, que en buena medida les fuera puesto desde fuera (aunque no se pueda negar la participación de los campesinos en su escalada), atacó a la sociedad andina desde múltiples lados, lo que vendría a significar que los protagonistas armados hacían simulacros mediante intercambio no solo de actiudes y formas de acción en las aldeas sino que también se camuflaban, intercambiando elementos de apariencia física e incluso participando en frentes opuestos. De hecho, para una parte importante de los habitantes de la provincia, los acontecimientos bélicos adquirieron, ante todo, la figura común del manchaytimpu ${ }^{7}$ como generador de una serie de traumas, desde el físico al psíquico y cultural, desde el individual al colectivo.

${ }^{7}$ Manchaytimpu significa del quechua "tiempo de miedo" (siendo a la vez una palabra compuesta del verbo quechua manchay y del sustantivo "tiempo", prestado del castellano); es un término endógeno y con una gran capacidad de formación de imágenes de la época del conflicto armado en los Andes, utilizado por los serranos tanto durante el período de operaciones militares (así lo demuestran los numerosos testimonios recopilados por los investigadores en ese 
De modo que, en la conciencia de los serranos, el conflicto interno empezó a ser representado no solo a través de las figuras de determinados participantes en las acciones armadas, sino también a través de una violencia provista de fuentes ideológicas, multifigurativa y ejecutora de la destrucción psicofísica del mundo andino. Una violencia, que acompañó en el día a día a los habitantes de la provincia, tanto bajo el signo de la política de atemorización y actitudes racistas mantenidas por ambas partes en conflicto, como bajo el de unos actos interminables de sadismo, terror y demolición, que marcarían indeleblemente el paisaje de la provincia con la ayuda de huellas de tipo físico: rastros de sangre, cuerpos mutilados, despojos humanos profanados, animales masacrados, edificios en ruinas y terrenos abrasados. La omnipresencia de las pruebas materiales de los crímenes perpretados, entre los cuales destacarían los cadáveres humanos expuestos intencionalmente en las plazas de las aldeas, en las calles de las ciudades, en los postes de tracción, en las cunetas de los caminos o en las fosas comunes, dominaron espacios (no)sociales de los Andes, cual un fenómeno permanente de "castigo ejemplar" aplicado por todos los protagonistas de las acciones armadas. Cabe añadir que estas exposiciones públicas cumplían una función concreta tanto con respecto a los habitantes de la provincia que aún seguían vivos, como con respecto a los que ya habían perecido. En cuanto a los primeros, se les forzaba a mostrar lealtad; en cuanto a los segundos, se les estigmatizaba con la falta de un entierro digno por no haberla mostrado. No obstante, es menester señalar que esta obra bélica de destrucción no siempre marcaba la cotidianidad de los serranos de modo material. La experiencia del terror podía adquirir formas igualmente dolorosas, aunque no de índole física, cuando el sufrimiento y la muerte de las víctimas se convertían únicamente en el objeto de sospecha y pensamiento de sus allegados. En particular, durante la primera década del conflicto, los habitantes de la provincia desaparecían masivamente en circunstancias nunca esclarecidas y con un final nunca conocido. ${ }^{8}$ De este

momento), como después de su finalización (lo que descubrí personalmente en 2005-2010 en el curso de mi estudio de campo en las alturas de Huanta y en el valle del río Apurímac, cuyos habitantes lo usaron a veces como sinónimo de la expresión más popular en español, "tiempo de violencia" o "época de violencia"). Con el transcurso de los años, el término manchaytimpu ha sufrido una especie de transculturación y hoy en día se utiliza con mayor frecuencia como un símbolo polivalente de las formas en que los serranos percibían su propia situación en el conflicto. A resultas de esto, se lo reproduce no solo en el campo de la ciencia (como, igualmente, sería el caso de este texto), sino tambíen en el arte, el periodismo o la actividad social.

${ }^{8}$ Estamos hablando principalmente del problema de los desaparecidos, esto es, de las víctimas de desapariciones forzadas. Su "ausencia" fue resultado de arrestos no registrados y de la falta de información sobre el destino posterior de los detenidos. Como método de lucha antisubversiva, se utilizó una práctica similar en el siglo XX en muchos países latinoamericanos. En Perú, todas las formaciones gubernamentales lo usaron y se convirtió en una de las soluciones sistemáticas en los procesos de pacificación de la provincia (existen también elementos de esta índole en 
modo, la observación "universalmente antropológica" de Luis-Vincent Thomas acerca de la muerte, como "la peor de todas las rupturas, pues deja tras de sí un humillante y repugnante cadáver símbolo de la ausencia", ${ }^{9}$ alcanzaría en el contexto bélico andino un transfondo lleno de paradojas. Dicho "cadáver" habría de traumatizar la provincia con su presencia, pero también con su ausencia. Mediante el cuerpo sin vida, sus despojos o, precisamente, mediante su ausencia misma, los protagonistas del conflicto reforzarían en común su gobierno del miedo, manifestándolo a través de diversas formas de violencia y ejemplos de crueldad. Inflingir daño y ultraje a las víctimas fue no solo un elemento táctico en la lucha, sino también objeto de rivalidad, lo que en la práctica significaría superar los consiguientes niveles (cada vez más altos) de cosificación del enemigo. Junto con las abundantes tradiciones de racismo esto produjo un enorme margen de error y permisividad para con los actos de ensañamiento entre los serranos, creando con ello un símbolo propio, exclusivo, de una profunda depreciación de sus vidas.

Y lo que es importante: desde el punto de vista de los aldeanos, todo ello testimoniaba de lo absurdo de las reglas de juego en este conflicto interno e indicaba, por tanto, una carencia de soluciones universales que pudieran garantizar su supervivencia. En consecuencia, cuando ellos observaban desde dentro los mecanismos del terror, comenzaban a diluirse los lazos de conexión causa-efecto y, como en una aleación propia de las experiencias límites que acompañaban a las acciones armadas, pasaban a inscribirse en el ambiente cultural andino y a formar parte integral del imaginario colectivo y, junto a éste, de la estructura de sus creencias. ${ }^{10}$ De ahí que, aun cuando las interpretaciones

las acciones de Sendero Luminoso, pero en su caso fue claramente de menor escala y se asoció más bien con el reclutamiento forzado en vez de con detenciones). Aunque el problema de los desaparecidos peruanos aún se está investigando, a mediados de 2019 se estimaba que su número podría llegar a más de 18.000 víctimas. Para un enfoque sociocultural y jurídico más completo, véase: TAmayo 2003, COMISEDH 2012, ŚniAdECKA-KotarSKa 2006, Rojas-Perez 2017, así como la investigación de la autora en Lima y Ayacucho en abril-mayo de 2019.

9 Thomas 2001: 2.

${ }^{10}$ Que entiendo aquí como una cosmovisión andina heterogénea, originada en tiempos prehispánicos, pero también influida por una serie de factores en el período colonial y en la actualidad (incluidos, en primer lugar, los procesos de cristianización, que difieren en su alcance y grado espacio-temporal de intensidad). Percibir una estructura similar como una reminiscencia "pura" del pasado precolonial de la Sierra no solo sería una absolutización de gran alcance, sino una falsificación visible de la realidad sociocultural contemporánea de los Andes. Cabe destacar que, entre las cuestiones analizadas, no se trataron las referentes al campo de la antropología de la muerte y el entierro. Esto se debe no solo a su extensión, ya que exigirían una investigación por separado, sino también al hecho de que solo están indirectamente relacionados con el tratamiento del tema propuesto en el texto. El tema de mi interés no son, así pues, los significados culturales de la muerte, el duelo y el entierro, sino la percepción de los serranos de sus propias experiencias del terror que, además del doloroso hecho de la pérdida de seres queridos y la omnipresencia de 
individuales del curso de los acontecimientos en la provincia resulten diferentes, según sea el perfil de los partícipes, su común denominador seguiría siendo la figura de la violencia experimentada por todos, tal y como, sobre la base de las visiones indígenas y de forma elocuente, la describiría el joven escritor peruano, César Rosales-Miranda, a su paso por Ayacucho recién terminada la conflagración:

La violencia había perdido timidez. Su cuerpo elástico atravesaba los vientos y se trasladaba por los cañones andinos, extendiendo sus brazos, disparando razones de metal, redoblando los ecos de sus disparos, apuntando con la cerviz hacia adelante, a una velocidad letal. Los lugareños le temían, las autoridades se abrían a su paso, porque hasta el mismo viento y los cóndores se volvían a los costados haciéndole reverencias. ${ }^{11}$

Tanto los testimonios recopilados por el autor de la cita a principios del siglo XXI e interpretados por él en forma de imágenes literarias, como los primeros relatos de los serranos, que más de una década antes se habían convertido en la base de estudios científicos sobre el tema de la violencia en la provincia peruana, contenían ejemplos de visualizaciones colectivas de muchos componentes del terror y testificaban lo que fuera generado por él, tanto en la zona de operaciones militares como fuera de ella, es decir, nuevas categorías en la psicosis de miedo. Cabe destacar que los rastros de la transferencia de las experiencias del miedo y el terror a las estructuras del imaginarium, visibles casi desde el comienzo de la guerra, eran a menudo ejemplos de formas de encontrar objetivos "racionales" para una violencia "irracional". Una tesis similar fue presentada por investigadores peruanos en la década de los 80 , basada en sus primeras observaciones del fenómeno de la simbolización de la violencia política en los Andes. Asimismo la mayoría de ellos subrayaba que las formas observadas de "racionalización" de las experiencias del sufrimiento presentaban un profundo

los cadáveres, contienen muchos otros elementos, tales como el sadismo, el miedo y la destrucción. Para más información sobre el significado cultural de la muerte y el entierro en los Andes, véase: RAMOS 2010 y Rojas-PEREZ 2017.

${ }^{11}$ Rosales-Miranda 2013:43. Este autor, de origen limeño, visitó en el 2001 Ayacucho. Su experiencia de la ciudad aún marcada por la tragedia de la guerra (incluidas las conversaciones con los habitantes) le inspiró a escribir una novela sobre el terror. Su contenido, aunque ficticio e impregnado de misticismo, se basa en los testimonios que había recopilado sobre la violencia y sus percepciones locales. Como resultado, es una historia sobre el "poder del terror en los Andes", en la cual, sin embargo, el autor no se enfoca mucho en el curso del conflicto. Su tarea consiste en reconstruir, principalmente a través de imágenes literarias, el ambiente de la psicosis del miedo, donde los actos de violencia experimentados por serranos han sido simbolizados y mitificados. De esta manera, la novela es parte de la corriente cultural surgida ya en la primera década del conflicto, inspirada en el "tiempo de miedo" y que atestigua su profunda penetración en varias áreas de la memoria, la postmemoria y el arte (incluida no solo la prosa, sino también la pintura, la música, la danza, el teatro y las artesanías). 
carácter sincrético, ejemplificando con ello la dinámica infiltración de diferentes tiempos y espacios del funcionamiento de los serranos. Así, en el contenido surgido de la simbolización emergente del mal y del verdugo, la historia y la tradición se mezclaban con la modernidad, el conocimiento empírico con el mito y el chisme, la esfera de lo sacro con la economía y la política, la aldea con la ciudad y el enemigo con el aliado. Sin embargo, todas las representaciones de terror "encontradas" indicaban que la población campesina se esforzaba por hallar una analogía entre sus experiencias históricas de violencia y el estado de cosas en curso a la sazón en la provincia, reconociendo invariablemente como eje de los eventos observados el mecanismo de explotación gratuita de los nativos para los propósitos de las élites. En otras palabras, aunque las formas de percibir el terror pueden haber sido variadas, todas parecían estructurar la lógica del conflicto "desde abajo" y asumirla como algo propio de la cotidianidad andina. ${ }^{12}$ Esta observación coincidiría con el enfoque clásico del problema según Gilbert Durand, por el cual la imaginación simbólica se convierte en un "factor de equilibrio mental". ${ }^{13} \mathrm{~A}$ la luz de los estudios mencionados, las reacciones surgidas de la esfera psicoemocional de los habitantes de la provincia andina ante el terror y la crueldad habrían estribado tanto en una estrategia de adaptación (mediante la sumisión y la indiferencia frente a los actos de agresión), como tambíen en el intento de comprender sus orígenes y reglas.

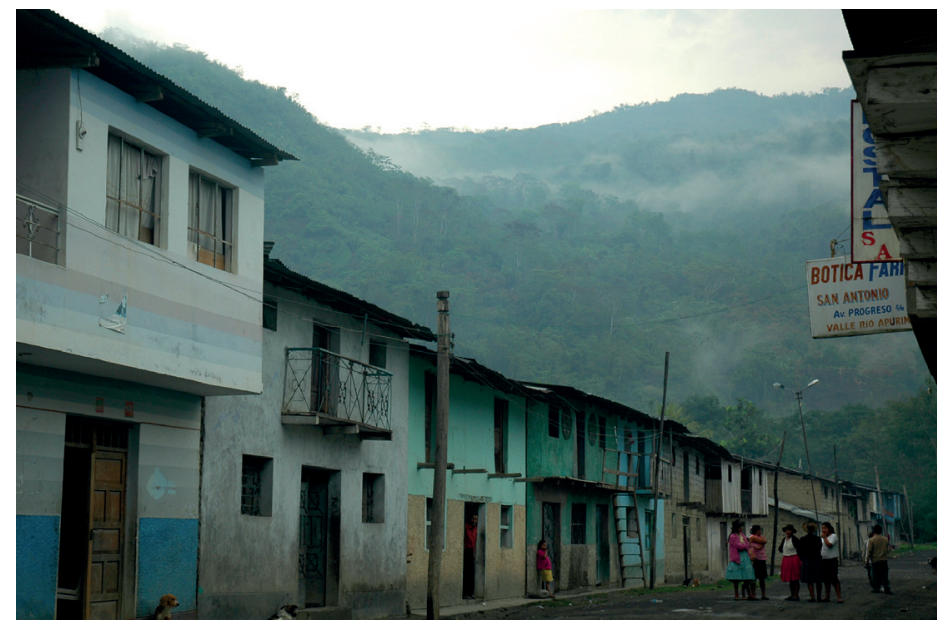

Fig. 3. Imagen actual del valle del río Apurímac; San Antonio, La Mar, septiembre de 2006, fot. J. Pietraszczyk-Sękowska.

12 Véase: Vergara, Ferrúa 1989 [1987], Degregori 2015 [1987], Granda Oré 1989, Portocarrero, VAlentín, YRIGOYen 1991 y en fuentes más contemporáneas: MANRIQUe 2002: 287-303, Vergara 2013, JodŁowska, MąKa 2016: 148-152 y Weismantel 2016: 253-254.

${ }^{13}$ Cit. en: JodŁowsKa, MĄKa 2016: 53. 


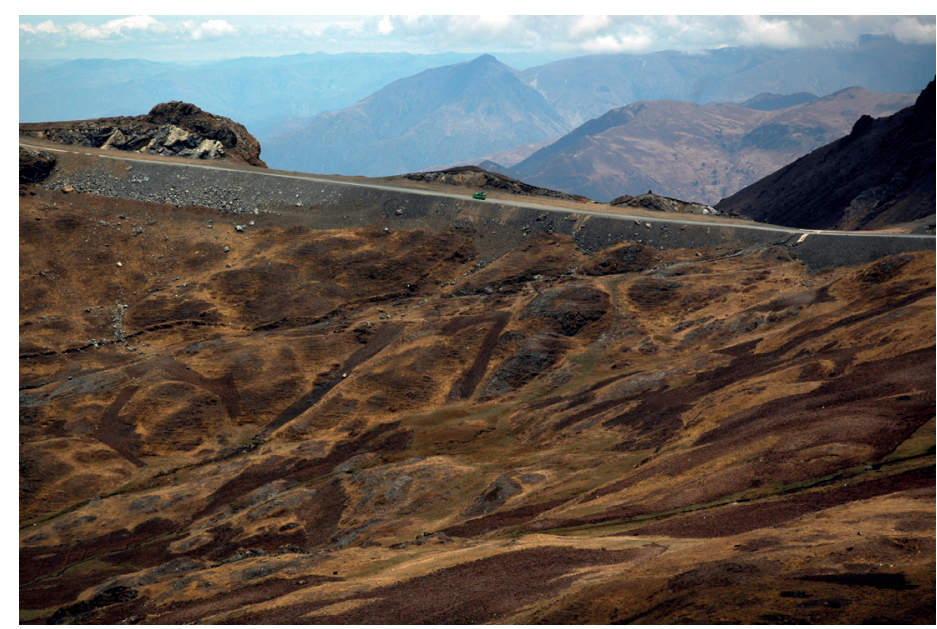

Fig. 4. Paisaje posbélico de la sierra de La Mar, septiembre de 2006, fot. J. Pietraszczyk-Sękowska.

Es obvio que este mecanismo también incluyó ensayos de darle sentido a los papeles de los protagonistas concretos de las operaciones militares. Como antes señalé, en la realidad de la lucha en la provincia, distinguir con nitidez sus figuras partícipes se hizo una tarea particularmente ardua (tanto a causa de la difusa línea demarcatoria entre las actitudes y las formas de sus acciones, como de su aspecto exterior, cuya diferencia resultaba empañada, a veces intencionalmente, cuando no imperceptible para los aldeanos). No es pues extraño que con el tiempo todos fueran adquiriendo el estatus de torturador en la conciencia de los comuneros. Como resultado, sus personajes fueron sometidos a una simbolización negativa, aunque este proceso tuvo un perfil claramente heterogéneo.

\section{(Por primera vez) Acerca de Sendero y el ejército al servicio de las MISMAS FUERZAS}

\section{Empecemos con una reflexión sobre el terror senderista ...}

A la luz de los testimonios de los habitantes de la provincia, parece que, al menos en el campo del imaginario colectivo, el mal se visualizó con mayor frecuencia en relación a los representantes del Estado. Tamaña regularidad podría explicarse en clave de "lo ajeno", ya que en los primeros años del conflicto, los oficiales de la tropa presentes en la provincia se destacaron por su diferencia étnica, social y política con respecto a los autóctonos, lo que provocaría, 
por otra parte, un mayor uso de la violencia. ${ }^{14} \mathrm{Si}$ bien también los senderistas serían considerados con el tiempo como hacedores de destrucción, sus imágenes fueron exotizadas menos frecuentemente dentro del contenido de las representaciones colectivas. Esto podría deberse al hecho de que los aldeanos se topaban sobre todo con los mandos de campo y los miembros de la organización subordinados a ellos, es decir, con personas del ambiente andino y, lo que es más importante, con personas que se esforzaban por darle un sentido a su actividad en la provincia. A pesar de los intentos de adaptación mutua entre ambas partes, es decir, de adaptación del discurso revolucionario a las necesidades de la aldea andina y de sometimiento simultáneo de los comuneros a los desafíos generados por el conflicto armado (en ambos casos fragmentarios y coyunturalistas), no pudo evitarse un antagonismo gradual entre Sendero Luminoso y la población campesina, de lo cual, habría de decidir, aparte de una serie de condicionantes individuales, la creciente violencia en diversas direcciones. Si bien en el origen de la relación entre ambas partes el terror senderista tuvo exclusivamente un carácter selectivo, ya desde los primeros años del conflicto sorprendió a la población andina tanto por su forma como por sus objetivos. ${ }^{15}$

La práctica del terror ejercida por el grupo se basaba en los presupuestos de violencia ideológica que los senderistas habían enseñado a fondo a los campesinos y que los primeros denominaban "revolucionaria". La organización estaba convencida de la función estructural - creativa de la agresión, como herramienta para escribir la historia, lo cual en el caso del Perú significaba principalmente el acto de transformación política y socioeconómica llevado a cabo por la vía revolucionaria. Es más, la premisa de que la violencia puede ser fructífera le daba justificación científica (racional) y moral (redentora), y por ende la convertía en un fin en sí misma. Poner en práctica tales teorías implicaba tanto el sacrificio de la "cuota de sangre" por parte de los propios miembros de la organización, como los "baños de sangre" derramados entre los civiles por el

14 Más ampliamente en la parte ulterior del texto.

15 No cabe duda de que, a comienzos de los años ochenta, al menos una parte de la población andina veía la convergencia de sus propios intereses con los objetivos de los senderistas y, por ende, simpatizaba con ellos o incluso se decidió cooperar más o menos abiertamente con la organización. Sin embargo, la resistencia a Sendero Luminoso, mencionada anteriormente, nacería de una forma relativamente rápida. Aunque podía aparecer en cada una de las aldeas en circunstancias ligeramente diferentes, solía constituir una clara respuesta a su abuso del poder y a su violencia, equivalente a la violación de un univoco principio andino el de "castiga pero no mates". Este tema tan complejo ha sido relativamente tratado. Incluso durante el conflicto en el Perú, fue abordado por Berg (1986), Manrique (1989), Coronel y Loayza (1992), Coronel (1996), del Pino (1992 y 1996), Degregori (1985, 1992, 1996b), Isbell (1994). También fue incluido en: CVR 2003, MANRiQue 2002, del Pino 2017 y en la tesis de doctorado de la autora (PietraszCZYK-SĘKOWSKA 2011) y se verá más desarrollado en la monografía Comuneros na wojnie, preparada para publicación por WUŁ en 2020. 
partido. La primera, "la cuota de sangre", debía ser una manifestación del martirio de los senderistas y estaba prevista en su ideología, en tanto que el "baño de sangre" establecía una escalada de terror, que a nivel táctico servía de intimidación y purga político-social en el seno de las comunidades aldeanas y estratégicamente constituía en una herramienta para cambiar el sistema. ${ }^{16}$

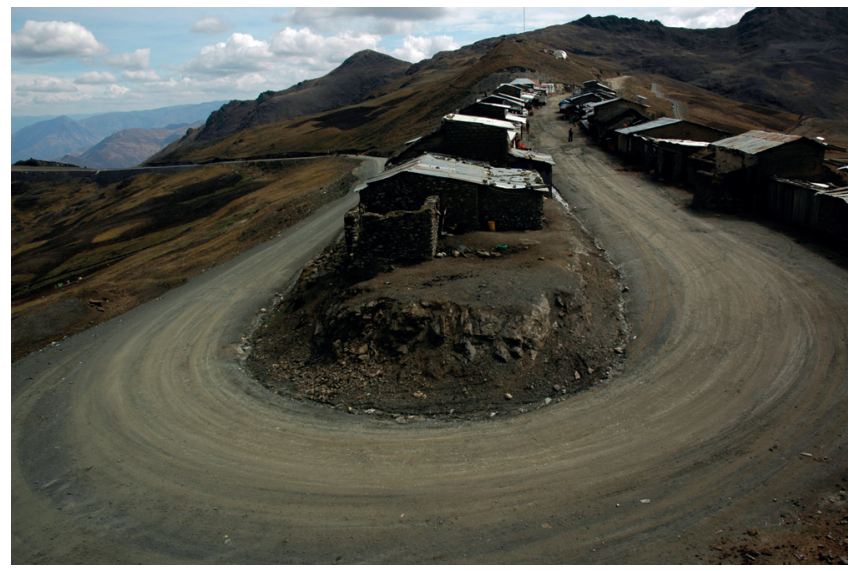

Fig. 5. Imagen actual de la comunidad de Pacobamba (La Mar) diezmada por la violencia política en los años 80; septiembre de 2006 fot. J. Pietraszczyk-Sękowska.

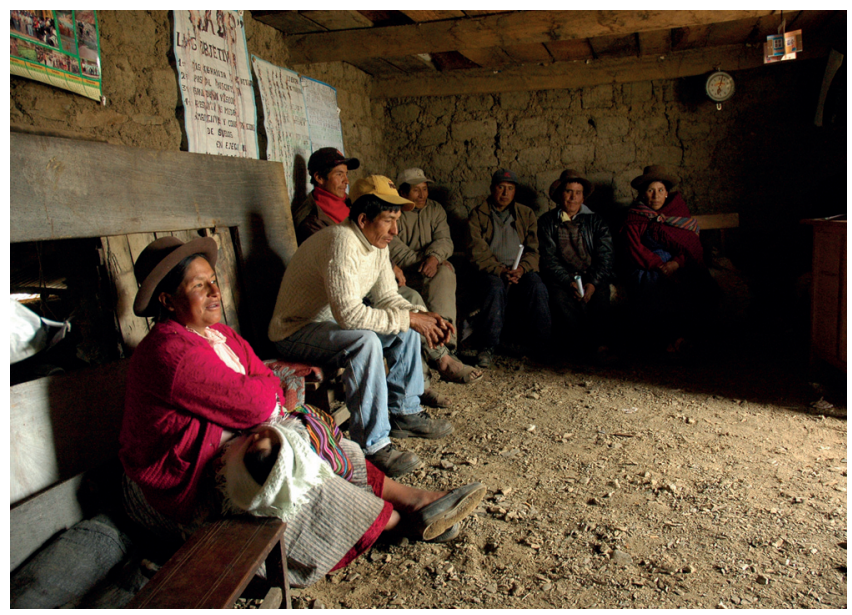

Fig. 6. Reunión de la junta directiva para discernir los objetivos y condiciones de la visita de la autora al lugar; Pacobamba, La Mar, septiembre de 2006, fot. J. Pietraszczyk-Sękowska.

${ }^{16}$ Más en los excelentes estudios sobre la violencia durante la guerra en el Perú: FLORES GALindo, Manrique 1986, Portocarrero 1998, MAnrique 2002, Vergara 2009 y 2013, JimÉnez 2009, DeGREGORI 2003 y 2013. 
La implementación de estos presupuestos en las condiciones de la provincia peruana hizo que sus habitantes no solo se convirtieran en un sacrificio necesario, sino también de bajo costo, y cuyas dimensiones habrían de aumentar conforme al orden dialéctico. La violencia ideológica, destinada a "purificar" moralmente el espacio andino, pronto aparecería, a los ojos del colectivo local, como hábil conductora de su propia deconstrucción, pues los individuos, que desempeñaban roles sociales clave en sus estructuras, y a menudo sus familias, eran a priori eliminados. Cuando a los actos selectivos (pero sistemáticos) de terror perpretados por los senderistas se añadieron, con un alcance mucho mayor, la represión masiva a manos de las fuerzas armadas y de sus aliados civiles $\mathrm{y}$, poco después, los sangrientos estragos de la rivalidad entre ambos actores, todo ello con el fondo adicional de una crisis económica que se extendía desde las ciudades, los pueblos andinos se contemplaron en el espejo de la aniquilación. De esta manera, a despecho de lo predicado por los ideólogos del senderismo, ya a fines de la primera mitad de la década de 1980, las decisiones estratégicas del partido dejaron de ser el principal determinante direccional en el incremento del terror en la provincia. A la luz de las declaraciones de mis interlocutores, en las zonas rurales, la autoridad fue sometida a un proceso aniquilador, que ellos dan en llamar "locura", "bestialidad", "temor", "sinrazón" o simplemente "maldad". ${ }^{17}$ La paradoja del (des)orden de los acontecimientos en la provincia ha sido expresada de forma escueta por C. I. Degregori, no sin prestar también atención al factor psicocultural como un determinante significativo en las actitudes de la población andina involucrada en el conflicto:

Sendero Luminoso no advirtió que el carácter prolongado de la guerra y su estrategia de construir bases de apoyo, chocaban con las concepciones de tiempo y espacio del campesinado, porque al fin y al cabo estas concepciones le importaban poco o nada [...] Guerra popular hacia fines de los años ochenta parecía alargarse en ciclos interminables de establecimiento, restablecimiento y contrarrestablecimiento ... ad finitum. ${ }^{18}$

Según el investigador, a juicio de los serranos, la obra de destrucción se apoderó de la provincia. Los testimonios recopilados, tanto durante el conflicto

${ }^{17}$ Los estudios de campo de la autora en el valle del río Apurímac (septiembre de 2006, noviembre de 2007), ciudad de Ayacucho (noviembre de 2007, enero de 2010, mayo de 2019), distrito de Chaca (enero de 2009), valle y alrededores de Huanta (noviembre de 2007, enero de 2010) y zona Putis (octubre de 2015, junio de 2016, mayo de 2019).

18 Degregori 1996b: 215-216. En los conceptos "establecimiento, restablecimiento y contrarrestablecimiento del poder" citados por Degregori radica la esencia de la "guerra popular" según la doctrina maoísta. Su estrategia consistía en el desarrollo en tres etapas de la lucha armada, comenzando por la implantación del poder temporal de los revolucionarios (establecimiento), su renuncia posterior ante la ofensiva del gobierno (restablecimiento) y la victoria final de las fuerzas revolucionarias (contrarrestablecimiento); para más véase: GuZMán 1988. 
como en la actualidad, muestran que, a pesar de la diversidad inicial de las actitudes de los campesinos hacia las acciones de la organización, a medida que se fue desarrollando su lucha armada, se le fue achacando, de un modo relativamente unánime, la responsabilidad en la espiral de violencia desatada en los Andes. ${ }^{19}$ Ésta última cobraría, en la conciencia de los comuneros, la forma de una fuerza materializada cuyo "cuerpo elástico", como ya escribió el citado Rosales-Miranda, "atravesaba los vientos y se trasladaba por los cañones andinos". Cuando escribimos acerca de la percepción de la violencia en la provincia, cabe preguntarse si los causantes directos del terror senderista también se vieron influidos por el proceso de simbolización. Esta cuestión constituye un difícil desafío para el investigador, principalmente debido al hecho de que las posturas de los campesinos frente a las fuerzas del Sendero Luminoso no solo evolucionaron, sino que también se individualizaron a lo largo del conflicto. En consecuencia, los relatos actuales de los serranos sobre dicho tema contienen solo reflejos de sus visiones al inicio de la lucha armada. Es más, en la bibliografía sobre la violencia en los Andes, este asunto aparece solo episódicamente, y su discusión no se basa tanto en el análisis del problema, como en las propuestas de interpretación de las narraciones locales acerca de los senderistas, que, en consecuencia, suelen contradecirse. Por lo tanto, sabemos poco de esta cuestión. Con todo, un motivo, relativamente fidedigno, inscrito a Sendero Luminoso en el imaginario colectivo de la provincia sería su vínculo con el personaje de pishtaco, también conocido en Ayacucho como nakaq. Estamos hablando aquí de la criatura que, según las creencias indígenas, siembra el miedo, que proviene de fuera de los Andes y que se posesiona de sus lugares recónditos con el único propósito de asesinar a los indios y sacarles la grasa, de la cual se alimenta, por lo que en la literatura peruana también se la suele conocer como degollador andino. ${ }^{20}$ Según los amplios estudios sobre la función de este fenómeno a lo largo de la historia, la figura del pishtaco, como elemento de trauma cultural, "regresó" regularmente a los Andes durante varias crisis, macro y micro sociales, que sin duda también incluyen el período de conflicto interno de finales del siglo XX. De ahí que el motivo del pishtaco en el marco del terror desatado por Sendero Luminoso fuera mencionado ya en la bibliografia científica de mediados de la década de los 80. Sin embargo, en el trabajo del historiador

19 Véase entre otros: Vergara, Ferrúa 1989 [1987]: 128, Portocarrero, Valentín, YriGOYEN 1991: 56, MANRIQUe 2002: 289-293, JimÉNEZ 2009: 100-117, así como los estudios de campo de la autora en las aréas rurales de las provincias de Huanta y La Mar entre los años 20052010 y $2015-2019$.

20 Véase la extensa bibliografía peruana y extranjera sobre el tema del pishtaco: Ansión, SIFuentes 1989 [1986], Ansión 1987, Vergara, Ferrúa 1989 [1987], Degregori 2015 [1987], Portocarrero, Valentín, Yrigoyen 1991, Vergara 2013, Jodlowska, MąKa 2016, WeisMANTEL 2016 y la parte ulterior del artículo. 
peruano A. Flores Galindo, la criatura no ejemplificó literalmente la forma en que los comuneros representaban a los senderistas. El investigador, en cambio, vería en ello una herramienta para amedrentar a la población campesina, utilizada intencionalmente por las fuerzas gubernamentales para estimular las asociaciones de la figura del degollador con el terrorismo senderista y, por lo tanto, para provocar que los campesinos eliminaran físicamente a los miembros de la organización cuando apareciesen por las aldeas. ${ }^{21}$ Casi al mismo tiempo, el antropólogo de Ayacucho, Juan Ansión, al profundizar en los roles y las formas del fenómeno en la historia de los Andes, observó que la figura de pishtaco, en su retorno a contextos sociopolíticos cambiantes, estaría sujeta a diversas adaptaciones plásticas. En su una monografía sobre tradiciones míticas de Ayacucho, publicada en 1987, estableció que "el nakaq puede también tomar nuevas formas", ${ }^{22}$ lo cual incrementaría el interés acerca de las imágenes del fenómeno durante la guerra civil. A su vez, en su análisis sobre la cultura de la región, Billie J. Isbell llegaría hasta los ayacuchanos, quienes no dudaron en identificar a los senderistas con el pishtaco descrito como "una criatura carnívora, alimentándose de una población de la que ya no es posible sacar grasa", ${ }^{23}$ es decir, como es fácil de adivinar, agotada físicamente por el conflicto. Al igual que en Isbell, en otras percepciones de este período, el carácter del degollador, de acorde a su génesis, seguía siendo un forastero y un extraño entre la población andina. ${ }^{24}$ Por su parte, los investigadores contemporáneos del asunto, los polacos, E. Jodłowska y M. Mąka en su concepto de "nuevo nakaq" y en la figura de los senderistas insertada en él, vieron un espacio de profunda transformación del fenómeno, pues por primera vez comenzó a referirse a personas que sí procedían del mundo andino, pero que a resultas de haber perpetrado actos violentos sin sentido, habían perdido sus características. Como escriben los autores, la revolución "supuso un viraje decisivo en la división monolítica hasta entonces entre orbis interior y orbis exterior", por el cual "una parte de «los suyos» se trasladó al grupo de «los otros»". ${ }^{25}$ Según mis apreciaciones, desde este enfoque, resulta harto interesante destacar el hecho de que, si una tal exclusión de verdad se produjo, fue como fruto de una producción de violencia inusitada en los Andes, simbolizada, empero, con sangre, no con "grasa de indios",

${ }^{21}$ Flores Galindo 1986: 27 (el mismo motivo también apareció en: Vergara, Ferrúa 1989 [1987]).

22 ANSIÓN 1987: 179.

${ }^{23}$ IsBeLl 1994: 92-93.

24 Véase: Vergara, Ferrúa 1989 [1987], Degregori 2015 [1987], Granda Oré 1989: 118121, Vergara 2013, Weismantel 2016: 253-254; también vale comparar con: ANsión, SifueNTES 1989 [1986] y ANSIÓN 1987.

25 JodŁoWsKa, MąKa 2016: 152. 
como parte del fenómeno de adaptación del nakaq a la realidad del conflicto armado. ${ }^{26}$

\section{... y terminemos con una reflexión sobre la muerte y el sufrimiento infligi- dos por el ejército}

Con independencia de la universalidad del simbolismo presentado, que por supuesto se puede discutir, en estas imágenes del terror desatado en la provincia se hace difícil ver la implementación directa de las etapas de la revolución marcadas por los ideólogos del senderismo y señaladas con anterioridad. Muchos de los elementos comúnmente conocidos del conflicto en la provincia y las formas de ser captados por los serranos difieren tanto del plan de la "introducción", es decir, la toma de poder temporal en el país por el partido, como de la "reintroducción", o sea, la contraofensiva por parte del Estado. Según la lógica de los senderistas, se consideraba que la primera causaría en el Perú una escalada incontrolada del terror con participación de las fuerzas gubernamentales, la cual sin duda se dio, pero estuvo harto limitada en el espacio y el tiempo, se zafó claramente de las formas establecidas por el partido y, sobre todo, no condujo al objetivo esperado por ellos, es decir, la llamada "contrarreintroducción”, el asalto final al poder en el país. Como señalé, a principios de la década de 1980, el Estado reaccionó a la actividad de los senderistas en la provincia por medio de la violencia masiva y la crueldad, pero no tardaría tanto en reconocer lo contraproducente de tales soluciones entre los serranos. Para determinar qué motivos llevaron a las fuerzas gubernamentales a cambiar de actitudes hacia los campesinos, es necesario examinar las formas de experimentar y dar sentido al terror estatal en los primeros años del conflicto por parte de estos últimos.

Con el fin de emprender tal análisis, valdría la pena remitirse a ejemplos de relatos de base sobre los mecanismos de la violencia en la provincia. En su gran mayoría, muestran que el conflicto, fuente de trauma, significó para los pueblos andinos, principalmente, una sensación de pérdida de la gestión sobre su propio destino, engendrada por el autoritarismo del Sendero Luminoso y multiplicada por el terror del Estado (que siguió intrincándose, indudablemente, por la participación de varios civiles). Este último más a menudo se ejemplifica con referencias a actos de exterminio de aldeas y/o violaciones de mujeres y arrestos en masa, que implicaban a su vez el horror de los interrogatorios y la presencia de la tortura. Lo que es importante, este hilo temático, hoy en día

${ }^{26}$ Sin embargo, aún no me siento capaz de confrontar la importantísima interpretación de estos autores con los resultados de mi propia investigación, porque los testimonios que recogí en Ayacucho sobre la simbolización de las figuras de torturadores del periodo del conflicto se referían en su inmensa mayoría al Estado y a sus funcionarios (sobre esto hablo en este artículo más adelante). 
comúnmente conocido, de las experiencias sufridas por la población campesina por parte del Estado sería rara vez abordado en los relatos de los comuneros durante el primer período de mi investigación. Uno de los pocos testimonios recogido por aquel entonces sobre el problema fueron las palabras de un habitante de Chaca en las alturas de Huanta, quien representaba la generación más vieja del lugar:

Me entregaron al ejército, junto con seis personas más, ellas eran de otras comunidades. Nos metieron en calabozo, con manos y pies amarrados.... Estaba preso en base de Santillana, allí en pequeño cuarto me torturaban. Me pegaban fuerte en estomago, sienes..., hasta hoy sufro con problemas digestivos. No me daban de comer, nada..., o sea traían comida pero en mis ojos comían todo los soldados. Tanto me dolía barriga que frotaba fuerte las manos, así desamarraba soga, luego con manos calmaba dolor de estomago. Cuando me encontraron otros soldados los expliqué todo y me dejaron en paz. Me soltaron después de tres meses. ${ }^{27}$

Aunque la declaración de mi interlocutor pueda parecer extremadamente detallada, cotejándola con otras recogidas en el mismo período, esto se explicaría por el hecho de que su autor había estado implicado en diversas actividades para su aldea, tanto antes como durante el conflicto. ${ }^{28}$ Los testimonios de los comuneros en los años posteriores de la investigación, ya más numerosos, nos aportan un mensaje similar con respecto al trato recibido por la población campesina a manos de las fuerzas gubernamentales:

Aquel día, como siempre, subimos a tres caballos nuestros productos agrícola y fuimos así al mercado de Huanta. Justo cuando todo el mundo preparaba comida para sus familiares, apareció marina y empezó a arrestar varones de Culluchaca. Yo lo ví todo: los agarraban a ciegos y después metían a una camioneta como la leña - uno por encimas del otro. Eran catorce personas, junto con mi padre. Las familias enteras de frente se pusieron a buscarlos por todas partes: donde marina, Policía de Investigación, Guardia Civíl. Me acuerdo de que en las salas de marina había unas jaulas, como para las gallinas, pero en estas había gente - todos muy flacos del hambre. ${ }^{29}$

27 Testimonio de un exmiembro de las autoridades de la aldea (62 años); conversación en su casa familiar en Chaca, provincia de Huanta, el 18 de enero 2009.

${ }^{28}$ Por lo que él y sus familiares habrían de pagar un alto precio en muchas ocasiones. Cabe mencionar que su franqueza también se podría haber dado al hecho de que en el transcurso de mi trabajo de campo, su familia intentaba hallar alguna posibilidad de indemnización para él por parte del Estado, incluso en forma de fondos para tratamientos médicos; investigación de la autora en Chaca, enero de 2009.

29 Testimonio de un comunero de Culluchaca en provincia de Huanta (40 años); conversación en un restaurante huantino, el 13 de junio 2016. 
Esos tiempos nosotros nos retirábamos lejos, sin comer. Pobre niños lloraban para comer, hasta comían pastos. Casi dos años escapábamos y en la selva hemos pasado. Esperamos en cerro - sin comida, sin nada. Nos agarraron militares y llevaron a Ayacucho, cuatro personas: a mi, Pedro, Gabino y uno que ya está muerto. Era de edad de 35 años, en ' 84 era. Nos han torturado unos quince días. Día y noche torturados. Con manos amarrados saltaba en pozo con agua. «Usted es jefe de terrucos»-me hablaba a mí. «Dónde está tu arma?». «Yo no conozco terrucos»- decía yo. Hemos declarado que no conocemos nada en la investigación. «Teníamos miedo y por esto al cerro escapábamos» dije yo. Primero yo declaré, igualito los tres declararon. Hemos salido después de quince días, sin comida, sin nada. ${ }^{30}$

Los relatos de la población andina, procedentes de varios períodos y regiones afectadas por el conflicto, resultan sumamente acordes en cuanto a forma de percibir su propia posición en el trato mantenido con los "uniformados". En todas ellas predominan la conciencia de la depreciación de los campesinos a los ojos de los funcionarios estatales, a causa, entre otras, de la cuestión ya antes mencionada del enorme margen de error concedido a las acciones antisubversivas en las aldeas, del sentimiento de hallarse ante los mecanismos deshumanizantes del manchaytimpu, de la comprensión de lo harto estigmatizante del origen andino y de la convicción de la imposibilidad de influir en su destino y en él de sus seres queridos en caso de arresto. Esta última experiencia goza de un estatus especial entre las otras fuentes del trauma, que emanan no solo de lo sorpresivo de las detenciones y del desconocimiento a largo plazo del destino de los detenidos (grabados además en la memoria de comuneros como embrutecedores por las diversas formas de torturas psicológicas y físicas), así como por el miedo producido cuando se organizaban, bajo múltiples pretextos, intentos arriesgados de encontrarlos en el interior de las instalaciones militares. ${ }^{31}$

${ }^{30}$ Testimonio de un desplazado de la zona de Putis (65 años); conversación en su casa familiar en Rodeo-Putis, provincia de Huanta, el 18 de junio de 2016. Los nombres de personas han sido cambiados.

${ }^{31}$ La investigación de la autora en las alturas de Chaca (enero de 2009), valle y alrededores de Huanta (noviembre de 2007, enero de 2010) y zona Putis (octubre de 2015, junio de 2016, mayo de 2019). 


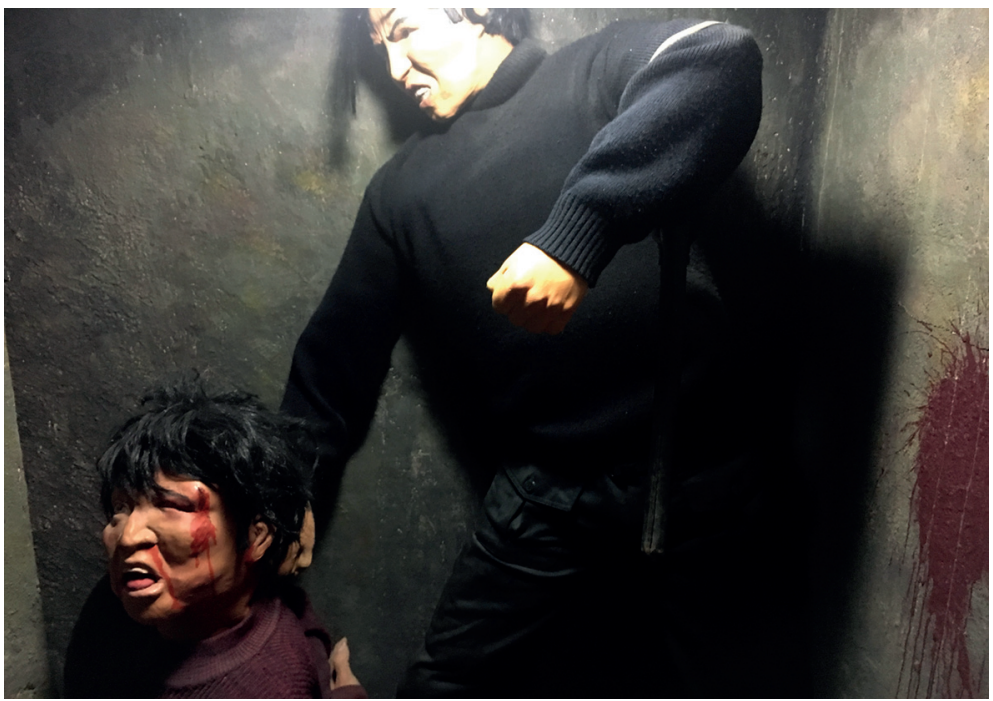

Fig. 7. Representaciones actuales sobre la crueldad del ejército hacia los serranos; reconstrucción de una sala de interrogatorio en el Museo de la Memoria, Ayacucho, mayo de 2019, fot. J. Pietraszczyk-Sękowska.

En consecuencia, aunque no cabe duda de que en las formas de representar la experiencia del miedo y el terror durante el período de conflicto prevalece la simbolización negativa de las actitudes y personajes del bando gubernamental, su estudio no es para nada una tarea fácil. Además de la complejidad de la causa-efecto de la violencia en los Andes, ya descrita con anterioridad, a día de hoy al menos tres cuestiones más obstaculizan el análisis y la categorización en cuanto al modo de percibir el terror de las fuerzas armadas por parte de los serranos.

Ante todo y en primer lugar, a diferencia del caso de los senderistas, la violencia ejercida por las fuerzas gubernamentales se entrelazaba íntimamente con la larga historia de las relaciones mantenidas entre la población andina y el llamado "hombre de uniforme" como principal representante del poder estatal en la provincia. Aunque, tal y como ya escribí, Sendero Luminoso también fue considerado en las aldeas como un patrón (además, también armado y uniformado), su ataque al Estado (desde el punto de vista de los campesinos, una instancia tan abstracta como represiva), al menos al comienzo del conflicto lo había eximido de las asociaciones mentales de los andinos con los estereotipos "militares". Por el contrario, las figuras de los miembros de las fuerzas gubernamentales se remitían con fuerza al arquetipo del verdugo uniformado, surgido en un lejano pasado (es posible que todavía fuera prehispánico y luego 
colonial) y reproducido a su vez por las intervenciones militares habidas en los Andes a lo largo de los siglos XIX y XX, así como por las actitudes profundamente racistas y las prácticas corruptas perpetradas por las fuerzas policiales en la provincia antes de que estallase el conflicto. ${ }^{32}$ Erigidas sobre la base de estas tradiciones, las imágenes de los actos cometidos por los uniformados entre los serranos formarían el fondo para las nuevas experiencias de la población campesina en su contacto con el gobierno, adquiridas a consecuencia de un proceso de retroalimentación de la historia andina.

El siguiente problema lo constituye el hecho de que el conocimiento de la realidad de las operaciones militares en los pueblos andinos y la respuesta de estos a la violencia contra los civiles resultó prácticamente inaccesible durante toda la década de los 80 . Si bien es verdad que en los primeros años del enfrentamiento armado, los periodistas de Ayacucho habían informado en un tono alarmante sobre la escalada del terror en la provincia, a principios de $1983 \mathrm{su}$ trabajo de campo se vio interrumpido por el cierre del acceso a la zona de operaciones militares a instancias de sus comandantes, lo que no fue sino una reacción al inquebrantable interés de la prensa sobre las circunstancias de los crímenes perpetrados en la alturas de Huanta (para ser precisos, sobre su búsqueda de huellas de la participación del ejército en los mismos).$^{33}$ De esta manera, debido al creciente alcance del poder de las fuerzas armadas en las áreas afectadas por el estado de emergencia, la única fuente de conocimiento sobre la situación en la región era la cobertura controlada de los medios de comunicación, cuyo contenido dependía casi exclusivamente de las pautas establecidas por la propaganda militar. Debería esperarse hasta principios de la década de 1990 para que los primeros testimonios no gubernamentales sobre los mecanismos de la lucha del Estado contra el terrorismo, incluidos los rastros de la percepción del terror por parte de los comuneros, comenzaran a aparecer de modo selectivo en

32 Para el símbolo andino de "uniformado" desde la perspectiva de la antropología ver entre otros: JodŁowsKa, MĄKa 2016 y Ś́nIADECKA-KotARSKa 2006 y 2011. Para una perspectiva política y sociológica: ManriQue 2002, Tapia 1997, Hurtado Meza 2006, Stelmach 2010.

33 Se trata de dos asesinatos en masa que tuvieron lugar en enero de 1983 en las aldeas vecinas de Huaychao y Uchuraccay en las alturas de Huanta. En el primer caso, los jóvenes senderistas hallaron la muerte a manos de comuneros; en el segundo, las víctimas fueron unos periodistas que intentaban investigar el caso, dado que, como una buena parte de la opinión pública, no creían que el asesinato de los mandos de Sendero Luminoso hubiera sido una acción espontánea de los campesinos (la influencia de los "uniformados" en el curso de los acontecimientos sigue siendo un secreto a voces). Como nunca se han esclarecido todas las circunstancias de la muerte de los periodistas, el crimen ha sido objeto de diferentes procesos de simbolización y sigue siendo un tema de investigación que goza de gran popularidad hasta hoy en día. Además de numerosos estudios al respecto (véase, entre otros: Hosoya 2004, CRistóbal 2003, DEL PINO 2003, SALCEDO 2013); asimismo vale la pena conocer el nuevo enfoque propuesto ultimamente por: DEL PINO (2017). 
la bibliografía sobre el tema. ${ }^{34}$ No obstante, en ese mismo momento, el régimen de A. Fujimori introdujo nuevos estándares para la gestión de la crisis en las provincias, que consistían principalmente en aumentar su aislamiento y a la par intensificar la propaganda del triunfo del Estado sobre el senderismo. A resultas de estos factores, el acceso a la información de las fuentes en dicho campo presentaría serias dificultades en los siguientes años. ${ }^{35}$

Y la última de las trabas estaría relacionada con la complejidad morfológica del fenómeno en estudio, que deriva, a su vez, de al menos tres condicionantes: de la inserción de la violencia generada por el conflicto en un contexto cultural heterogéneo, de la variabilidad espacio-temporal de las percepciones del terror desde la base (imposible de reproducir en el presente por la ya mencionada falta de acceso a la provincia durante largo tiempo y, por lo tanto, a las fuentes populares de información sobre el conflicto), e igualmente, lo que debe subrayarse, de la multiplicidad de figuras del "hombre con uniforme" sujetas a interpretación: empezando por la del bando gubernamental visto como un monolito, hasta la selectiva, referida solo a sus unidades organizativas (principalmente sinchis y marina), pasando por la de oficiales concretos, identificados por los civiles con el nombre propio o, más a menudo, con un apodo de guerra). Estos factores crean imágenes ricas y a veces aparentemente contradictorias de los servicios uniformados en la conciencia de los comuneros, las cuales, con todo, suelen presentar numerosos elementos comunes. ${ }^{36}$

34 Véase entre otros: Manrique 1989, Gorriti 1990, Coronel, Loayza 1992, Del Pino 1992, TAPIA 1995.

35 Vale la pena mencionar que incluso en el primer período de mi investigación (2005-2010), todavía había una clara reticencia entre la población rural a compartir sus experiencias personales de los primeros años de la presencia de las fuerzas armadas en los Andes, que fue acompañada por una tendencia desde arriba a condenar las acciones de los senderistas. No fue sino hasta más de una década después del final del conflicto que esta actitud comenzó a dejar paso a la necesidad de dar un testimonio completo, determinada tanto por los esfuerzos para compensar el daño sufrido por el Estado como por su reconocimiento oficial del papel fundamental de los campesinos en la pacificación de la provincia.

${ }^{36}$ La investigación de la autora en el valle del río Apurímac (septiembre de 2006, noviembre de 2007), ciudad de Ayacucho (noviembre de 2007, enero de 2010, mayo de 2019), distrito de Chaca (enero de 2009), valle y alrededores de Huanta (noviembre de 2007, enero de 2010) y zona Putis (octubre de 2015, junio de 2016, mayo de 2019). 


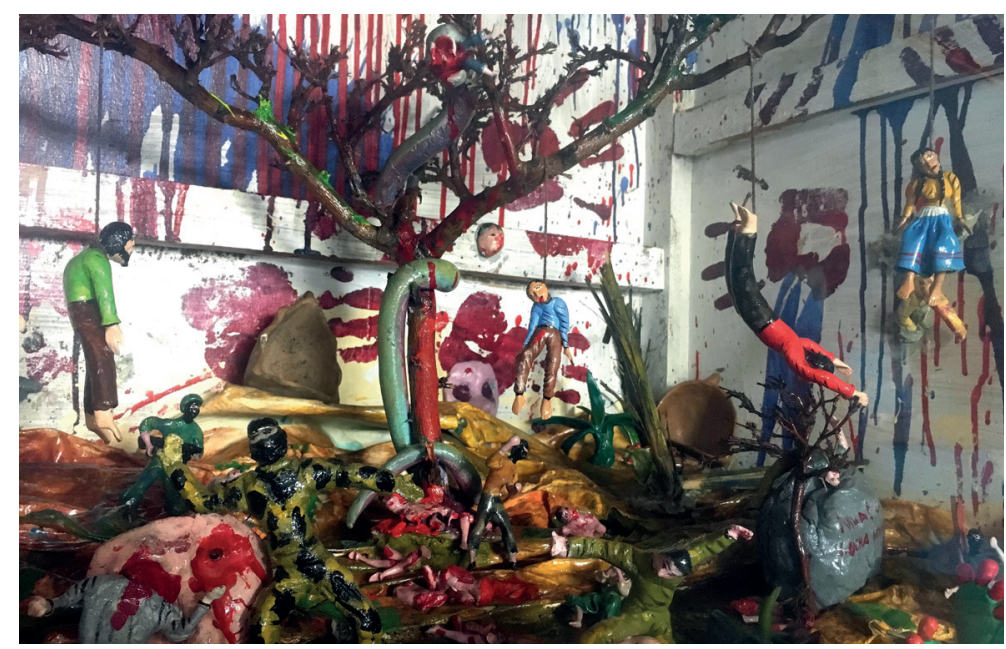

Fig. 8. Representaciones artísticas del caos y el sinsentido de la guerra en los Andes; fragmento del retablo en la sede de la ANFASEP, Ayacucho, mayo de 2019, fot. J. Pietraszczyk-Sękowska.

Así la esencia de las percepciones de base en cuanto a la violencia ejercida en los Andes por las fuerzas estatales parece reflejar de forma ilustrativa que, durante los primeros años de la lucha, fue común entre la población campesina, expuesta a su azote, creer que los militares activos en las provincias representaban nacionalidades no peruanas. Al menos dos factores favorecieron tales interpretaciones. El primero, definitivamente crucial, fue la tendencia del gobierno, señalada ya en repetidas ocasiones, a una crueldad inconcebible para la mente de los campesinos. El segundo, concierne al aspecto físico diferenciado de sus oficiales, dada su procedencia de las áreas costeras (de donde provenían tanto los sinchis y los marinas, como los miembros de los primeros contingentes del ejército de tierra). En el contexto de ambos fenómenos, los representantes navales fueron quienes obtuvieron, en primer lugar, el estatus de extranjeros, tanto por sus actitudes inhumanas hacia los habitantes de las aldeas, como por su gran altura, tez clara y su acento diferente del andino (es decir, características de una imagen con las que la mayoría de la población de la provincia estaba tratando por primera vez en su vida) y serían conocidos en los Andes como los argentinos. La génesis del término estuvo en el hecho de que durante la contienda civil peruana, en el Atlántico Sur se estaba librando también la guerra entre Gran Bretaña y Argentina por las Islas Malvinas-Falkland (marzo-junio de 1982), en la cual el Perú había apoyado a su vecino americano. De modo que los comuneros ayacuchanos consideraron que Lima había confiado la tarea de pacificar la provincia a las fuerzas argentinas como un elemento más 
de la alianza político-militar de ambos países. Pese a que, en realidad, las tropas que operaban en los Andes estaban constituidas por formaciones peruanas de élite, en el imaginario colectivo de la población campesina, la responsabilidad del terror generado se transfirió a un ejército extranjero. ${ }^{37}$

Es de destacar que tanto los ejemplos anteriores como muchos otros de simbolización negativa de actitudes y prácticas del bando gubernamental indicarían que, en la conciencia de los comuneros, el sadismo experimentado habría conducido a la deshumanización tanto del verdugo como de la víctima: el primero se habría desacreditado como representante de la especie humana y le habría privado al segundo de los restos de su dignidad como persona. Ya en los primeros años de la presencia de fuerzas estatales en la provincia, la imagen de su papel en el enfrentamiento se iba abasteciendo cada vez más con elementos del trauma cultural. Un ejemplo elocuente sería la figura de la "bestia cruel entrenada para luchar contra los indios", ${ }^{38}$ presuntamente vista por comuneros arrestados en lugares de aislamiento. Según los testimonios de estos últimos, las fuerzas de élite presentes entonces en la provincia disponían de tales criaturas, a las que guardaban dentro de unas jaulas en las salas de interrogatorios y utilizaban para amedrentar y mutilar a prisioneros indios con el fin de obtener sus confesiones. Al parecer se trataba de unos híbridos animal-humanos de gran fuerza física, pero completamente sometidos a sus amos (los militares), que los empleaban en sus torturas y asesinatos brutales mediante mordeduras. Pese a que las formas en que los comuneros representan a la "bestia" difieren algo en los detalles, es evidente que el convencimiento de su existencia había surgido de la combinación del trauma de las víctimas de las fuerzas gubernamentales con las creencias andinas, convirtiéndose rápidamente en un motivo ominoso de las narraciones de base sobre el manchaytimpu en la provincia. $\mathrm{Cu}$ riosamente, no ha quedado claro si hubo o no participación intencional de los mismos militares en la "llamada a la vida" de semejantes criaturas. Como ya he mencionado, los primeros investigadores del conflicto demostraron que fueron los métodos de intimidación utilizados por el ejército entre los andinos los que provocaron la psicosis del miedo al pishtaco. Existen varias razones para creer que un mecanismo similar también rigió el fenómeno bélico de la "bestia". En ambos casos, la creencia de los campesinos en la aparición de seres sobrehumanos amenazadores serviría, en efecto, al menos a dos propósitos esenciales

37 Este motivo aparece comúnmente en la bibliografía, sobre todo en la escrita durante el conflicto (véase entre otros: Galindo, MANRiQue 1986, Degregori 1996A: 19, IsBell 1994); también sigue siendo evocado por los comuneros hoy en día (lo escuché algunas veces en varias etapas y en distintas áreas de mi trabajo de campo).

${ }^{38}$ Fue así exactamente como me lo presentaron mis interlocutores de las alturas de Huanta, cuando nos encontramos por primera vez en la ciudad de Ayacucho en noviembre de 2007. 
de los "servicios uniformados": reforzar su control sobre la zona de conflicto a través de las leyes del miedo y reducir al mismo tiempo su responsabilidad en cuanto a las dimensiones del terror desencadenado. ${ }^{39}$

Si observamos el impacto de las acciones gubernamentales en el contenido del imaginario de los aldeanos, uno no puede evitar hacerse la pregunta de si los soldados que operaban en las provincia, no se habían convertido en el origen de las encarnaciones del degollador andino. La respuesta a tal pregunta no resulta obvia, debido tanto a las actitudes diversificadas de las fuerzas gubernamentales, como a la riqueza semántica del fenómeno aquí indicado. En cuanto a la cuestión de simbolizar directamente al ejército peruano mediante la figura del pishtaco, ha sido objeto de atención por parte de dos antropólogos polacos ya mencionados, Elżbieta Jodłowska y Mirosław Mąka. A su juicio, los ejemplos encontrados, en el contexto de la guerra civil, de imágenes negativas de miembros de las fuerzas gubernamentales habrían continuado con las ricas tradiciones de la figura del degollador andino con uniforme, al tiempo que gozarían de todos los elementos definitorios de su "extrañeza mítica", es decir, diversidad étnica, procedencia de un mundo exterior y falta de escrúpulos para infligir sufrimiento a los nativos. ${ }^{40}$ Sin embargo, durante mi estudio de campo de Ayacucho, no encontré rastros de conexión directa entre ambos motivos, lo

39 Este tema es uno de los motivos más interesantes de la simbolización del terror en los Andes. Aunque, como en el caso de los argentinos, trabé conocimiento con él a través de la bibliografía y también, en persona, a la luz de las narraciones de los comuneros la cuestión de la "bestia” es mucho más rara e incoherente, y sus imágenes resultan borrosas. Mis interlocutores la mencionaron esporádicamente y no pudieron describir el fenómeno con detalle (en sus relaciones, la bestia siempre era un híbrido animal-humano, pero apareció en diversas combinaciones de cuerpo humano y cuerpo de un lama o de depredadores). Por lo tanto, no pude sustraerme a la impresión de que todos la conocían solo por los cuentos de otros serranos, lo que concordaba al mismo tiempo con su creencia de que solo las personas detenidas podían mantener encuentros personales con la bestia. También me llamó la atención el hecho de que, según sus relatos, la criatura debía ser entrenada para luchar contra "los indios". Sin embargo, este término nunca lo usan los serranos con el propósito de autoidentificarse, sino que fue utilizado por las fuerzas gubernamentales con respecto a la población andina.

Rosales-Miranda, el joven escritor peruano ya mencionado, presenta el motivo de la "bestia" de manera ligeramente diferente (Rosales-Miranda 2011: 31-33). Según los testimonios que recopiló, la criatura provendría del área central de Ayacucho, pero fue retenida por el ejército en el cuartel ayacuchano de Los Cabitos, porque amenazaba a todas las personas. Se trataba de un animal "mutado por la naturaleza, con la cabeza de un lama, el torso de una mula y voz humana" (Rosales-Miranda 2011: 32). Curiosamente, a la luz de las fuentes estudiadas por el autor, su aparición se habría confirmado en la prensa y fue recibida por los habitantes de la provincia como un ominoso augurio del cataclismo mítico, que solo se podía evitar manteniéndola con vida. Sin embargo, tanto en caso de la investigación de Rosales, como la mía, el fenómeno fue impulsado por un rumor que aterrorizaba a los serranos, aunque la gente no estaba segura en absoluto de la existencia de la "bestia".

${ }^{40}$ Véase: JodŁowSKa, MĄKa 2016: 147-151. 
cual en modo alguno significa poner en tela de juicio las afirmaciones de estos investigadores, aun siendo también en la literatura peruana un tema extremadamente raro y ambiguo. ${ }^{41}$

No obstante, en base a esto último, se puede concluir que, en el contexto del conflicto interno, los mecanismos de influencia del terror de los militares en el fenómeno del "retorno" de los pishtacos a los Andes deben considerarse desde la perspectiva más amplia posible (también utilizada por E. Jodłowska y M. Mąka). Según este enfoque, su figura no tiene necesariamente por qué simbolizar torturadores concretos o sus acciones para convertirse en uno de los elementos de este paisaje bélico, puesto que, como ejemplo de trauma cultural, constituye en sí mismo una manifestación de los tiempos de crisis. Desde este punto de vista, el conflicto interno y el terror generado por él constituirían pues un modelo espacio-temporal idóneo para la actividad de los degolladores. Como ya escribí más arriba, no existe duda alguna de que ambas partes enfrentadas y sus acciones armadas cargan con la responsabilidad de tan sangriento panorama. Sin embargo, a la luz de las fuentes locales visibles en este periodo y en el imaginario de los aldeanos, los cuadros, multiplicados, de fuerzas demoníacas (incluidos no solo los supuestos nakaq vistos en lugares públicos, sino también la evidencia física de su actividad, como serían cadáveres exangues y con signos de mutilación en la garganta) cobrarían carácter metafórico sobre la política de Lima en la zona de emergencia. Según las interpretaciones de base, la psicosis desencadenada por el miedo y el caos reinante habría surgido a instancias de acciones intencionales del gobierno, cuyos representantes no tanto tomaban la forma de pishtacos, como, sobre todo, permitían que estas criaturas camparan a sus anchas por la provincia y ejercieran actos de crueldad contra sus habitantes, e incluso las habrían pagado a fin de realizar tareas especiales para el Estado. Curiosamente, fue en especial durante el gobierno de Alan García (1985-1990) cuando la cooperación entre ambas partes habría cobrado un carácter sistématico, a lo que contribuyó la singular convergencia de doble crisis, política y económica. En este complejo marco, la figura del degollador andino cumplió muchas funciones; no solo había servido para fortalecer el imperio del

${ }^{41}$ Estos investigadores trabajaron principalmente en otra área de los Andes y adoptaron una metodología diferente, poniendo su énfasis más en las fuentes halladas que en las inducidas. No obstante, en cada uno de los casos, el pishtaco siguió siendo el motivo principal de su investigación, en la que confrontaron una cantidad impresionante de materiales al respecto. En cuanto a mi trabajo de campo, la figura del degollador apareció como por casualidad durante las conversaciones acerca del terror con los habitantes de las aldeas, lo cual viene a significar que la fuente principal de mis datos fueron las entrevistas con los comuneros ayacuchanos. Y lo que también es importante: mantuve tales encuentros pocos años después de la guerra, cuando las posturas frente al ejército eran relativamente positivas y los relatos al respecto más contenidos que hoy en día. Vale comparar ambas perspectivas con: Vergara 2013 y WeISMANTEL 2016. 
miedo, que además se fue expandiendo clara y sucesivamente desde las zonas rurales hacia las ciudades. También habría librado un combate cuerpo a cuerpo contra el terrorismo, ${ }^{42}$ e incluso, en la versión más espeluznante para el pueblo andino, utilizaba el caos de guerra a fin de obtener preciadas partes de los cuerpos de los ayacuchanos, con las cuales ... se reembolsaba la creciente deuda externa del Perú, o se alimentaba a las fuerzas gubernamentales en la provincia. ${ }^{43}$ De todos modos, el pishtaco se convirtió en una parte "indispensable" del conflicto en los Andes y sus rostros pavorosos.

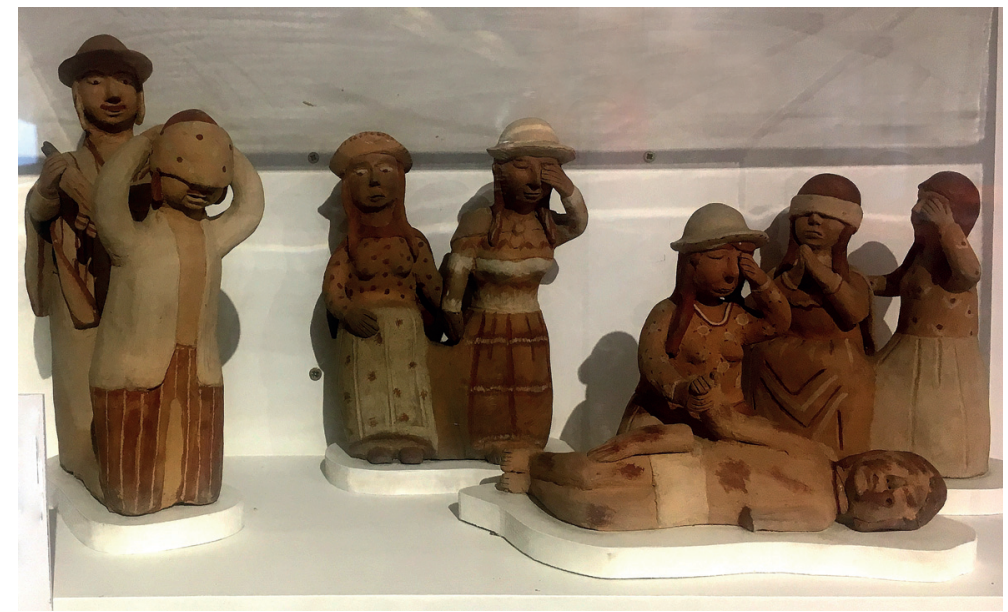

Fig. 9. Representaciones artísticas de la crueldad y el sufrimiento en el periodo del manchaytimpu; figurillas de cerámica de Rosalía Tineo, El Lugar de la Memoria, la Tolerancia y la Inclusión Social (LUM) en Lima, mayo de 2019, fot. J. Pietraszczyk-Sękowska.

${ }^{42}$ Esta tarea estuvo a cargo de los pishtacos antiterrucos, quienes al parecer poseían una "licencia firmada por el presidente Alan" (cit. en: Vergara, Ferrúa 1989 [1987]: 125) y buscaban grasa de senderistas para venderla. En otra versión del relato se habló de los paramilitares "con caras de pishtacos" que no se sometían a autoridad alguna de Ayacucho porque fueron mandados directamente desde Lima; véase: Vergara, Ferrúa 1989 [1987]: 125-133, Degregori 2015 [1987]: 111, Portocarrero, Valentín, Yrigoyen 1991: 54, Vergara 2013: 294-295, JoDŁOWSKA, MĄKA 2016: 99.

${ }^{43}$ En el primer de los casos, el material deseable sería, tradicionalmente, grasa, pero también sangre vendida a bancos europeos. En el segundo, se buscaría carne, luego servida en las cantinas de las unidades de la policía local; Vergara, FerRúa 1989 [1987]: 125-134, Vergara 2013: 294-302. 


\section{A MODO DE EPÍlOGO}

Cabe destacar que, con independencia de los detalles que pudieran diferir entre sí en las imágenes indígenas de los torturadores "gubernamentales", todas ellas reflejaban las progresivas escisiones que se iban produciendo en el seno del Estado y la sociedad peruanos. C. I. Degregori escribió ya sobre este problema en el contexto del terror de las fuerzas gubernamentales en la década de 1980, estableciendo la tesis de que el renacimiento de la figura del pishtaco "revela un repliegue, ya no solo sobre lo local sino sobre lo étnico y, por tanto, un desgarramiento profundo de los débiles tejidos nacionales que se habían ido forman do en la zona". ${ }^{44}$ Con un enfoque similar, el estado de la ciudadanía y la condición de las relaciones interétnicas del período de guerra fueron descritos por investigadores peruanos posteriores, haciendo éstos hincapié, de forma unívoca, en que una división semejante en las relaciones entre los serranos y el Estado constituía una manifestación de autodefensa no solo en el sentido físico, sino también psicoemocional. En el segundo caso, se trataba de un acto de separación mental del mundo que, a pesar de su obligación de proteger a los civiles, los había traicionado cruelmente. A tenor de las visualizaciones del mal y del verdugo presentadas en el texto, dicha traición no solo se plasmaría en los crímenes de guerra perpetrados, sino también en la explotación económica ejercida sobre los habitantes de la provincia en medio del caos bélico por un Estado "ajeno". ${ }^{45}$ Aunque esta visión de las bases se refería inicialmente al gobierno y a sus funcionarios, no tardó en superponerse y penetrar también en la imagen extraída de los senderistas. Tanto en el contenido verbal como visual de los testimonios comuneros, la figura del torturador va perdiendo paulatinamente la propiedad de utilizar la afiliación ideológica y el frente militar. En cambio, suele poseer características socio-raciales-étnicas similares: se trata de un extraño, un foráneo, un hombre de piel clara y cuerpo robusto (se lo compara a un toro), que a menudo se cubre el rostro, lleva barba, viste uniforme o abrigo y porta armas. Así pues las "encarnaciones del terror" en tiempos de guerra se inscribieron en las abundantes tradiciones de abuso y deshumanización de los serranos ya antes mencionadas y, en consecuencia, favorecieron el "retorno" de sus míticos enemigos. ${ }^{46}$

${ }^{44}$ Degregori 2015 [1987]: 112.

45 Véase: Vergara, Ferrúa 1989 [1987]: 125-134, Portocarrero, Valentín, Yrigoyen 1991: 55-57, VERGARA 2013: 294-302; también vale comparar esta perspectiva con: MANRIQUE 2002: 298-303.

46 Véase entre otros: Vergara, Ferrúa 1989 [1987]: 125-134, Portocarrero, Valentín, Yirigoyen 1991: 53-57, Manrique 2002: 295, Degregori 2015 [1987]: 111. Valdría la pena ampliar este tema a tenor de las imágenes que mi persona produjera entre los serranos de 
Aunque los fenómenos descritos parecen remitirse principalmente a las fuentes culturales, en su análisis, sería fácil caer en un error de culturalismo. Por ejemplo, una actitud semejante se manifestó en el campo científico a principios de la década de los 80 , cuando las huellas de la psicosis entre la población andina comenzaron a despertar, entre los investigadores, asociaciones con el renacimiento de las creencias en pachacuti. Estaríamos hablando aquí de un cataclismo generador de una inversión del tiempo que, tal y como parecía en aquel momento, la máquina de guerra aniquiladora podría estar anunciando. Sin embargo, la adopción de tal perspectiva se habría de vincular a la convicción del carácter milenarista de la revolución de Sendero Luminoso, que ya fue objeto de críticas de modo sustancialmente eficaz al final de la misma década, tanto más aún por cuanto, según esta lógica, una visión parecida del milenarismo andino conllevaría asumir ciertos elementos sobre el papel salvador del ejército. ${ }^{47}$ A su vez, C. I. Degregori propuso "reemplazar" la creencia de los andinos en el pachacuti por el de sentimiento de destrucción debido al chaqwa, es decir, a un estado de caos que para la provincia andina no significaba una inversión del orden pero una mezcolanza absurda. ${ }^{48}$

Ayacucho. Durante la etapa inicial de la investigación en las alturas de La Mar, en la aldea de Pacobamba, a lo largo de las conversaciones que mantuvieron conmigo, se abordó en varias ocasiones la cuestión de si mi persona hubiera estado "más cerca de un pishtaco o de una senderista". Según los pacobambinos, debido a la altura, la tez clara, el atuendo masculino y la mochila (el último de los elementos era particularmente importante), habría podido ser ambos. Aunque anoté conversaciones abiertas sobre este tema, solo una vez, en el estudio de campo, el caso me pareció sintomático. En primer lugar, sucedió en una aldea altoandina aislada que hoy en día se encuentra junto a la carretera que conecta la sierra con la selva, un lugar idóneo para la "caza" de los serranos tanto a manos de los pishtacos, como a manos de los senderistas (cabe añadir que los enfrentamientos de estos últimos con el ejército ya en 1984 provocaron la destrucción y despoblación totales de Pacobamba que después del conflicto fue reconstruida a lo largo de la nueva vía, es decir por encima de su ubicación originaria). Es más, las mujeres fueron quienes hicieron, principalmente, esta clase de consideraciones, es decir, quienes, también durante la guerra, habían manifestado sin tapujos el miedo a los foráneos y solicitado a los militares que los expulsaran de Ayacucho. A pesar de que en el transcurso de las conversaciones conmigo, este problema se trató en un ambiente amistoso y de un modo incluso anecdótico, tuvo un efecto paralizador sobre los niños, que claramente estaban embargados por la psicosis del miedo tanto al pishtaco como al senderista. Asimismo, es menester aclarar que mi visita a la aldea sucedió en el año 2006, es decir, poco después de la guerra, y los comuneros aún podrían tener miedo de la supuesta vinculación de cualquier forastero con Sendero Luminoso, ya que desde su punto de vista esto podría significar no solo la posibilidad del retorno del senderismo a los Andes, sino también de la represión encarnizada del ejército (el cual, por otra parte, se dejó caer en la aldea preguntando a los residentes por mí persona, pero evitando en todo momento hablar conmigo cara a cara).

47 Véase: Starn 1992, Degregori 1992.

48 Véase: Degregori 1992: 418; el investigador se remitió aquí a la interpretación del término chaqwa propuesta por dos antropólogos peruanos, J. Ossio y F. Fuenzalida, quienes lo usaron en un sentido similar en el contexto de los sucesos habidos en las alturas de Huanta en 1983 
La visión presentada por Degregori entre las décadas de los 80 y 90 está del todo conforme con el contenido de los relatos de los ayacuchanos que yo recopilaría más de una década después, según los cuales los mecanismos de violencia fratricida convirtieron el conflicto en la provincia en una "locura", un "sinrazón" o un "temor". Sin embargo, estos mismos materiales contienen otros ejemplos con rastros de actitudes "racionales" de los serranos en relación con los eventos "irracionales", lo cual también fue señalado por los investigadores en la década de los 80 . Según mis interlocutores, la reacción inicial de la población andina al terror masivo se caracterizó por el antes mencionado "regreso hacia lo étnico y lo local", ya que fue consecuencia de circunstancias en las que todos los demás mundos culturales se habían trocado en una fuente de peligro. En ese retorno específico a la matriz, que, valgan paradojas, al mismo tiempo podía ocultarse debido a su naturaleza estigmatizante, se buscaba auxilio en el plano mental y físico. El primero se enlazaba con un sentido de identificación dentro de una comunidad de cultura y experiencias; el segundo forzaba a la solidaridad intragrupal, seguida de las primeras acciones defensivas. Por lo tanto, se puede finalizar el análisis realizado en este artículo con la siguiente digresión: junto al contenido del imaginario colectivo, un componente importante de la actitud racional de los serranos radicó en el fenómeno de autodefensa campesina, lo cual nos conduce a otra paradoja muy importante de esta guerra; esto es, al hecho de haber armado a los civiles y de que estos buscaran formas de supervivencia mediante alianzas con sus propios verdugos. Alianzas, que se establecían en el marco de un enfrentamiento fratricida, con las que contribuían a una escalada del terror y con las que se generaba, entre quienes ellos mismos representaban, es decir, la población andina, un mayor espanto y una mayor sensación de caos. ${ }^{49}$

Traducido del polaco por Pilar Gil Canovas

(ver: Ossio, FuenZaLida 1983). En las traducciones literarias del quechua al español chaqwa y sus palabras derivadas se comparan principalmente con "griterío", "desintegración" y "destrozo", igual como con "desconcierto" (ver: Calvo Pérez 2009: 1526-1527, Guardia Mayorga 1997: 67-68).

49 Las circunstancias del nacimiento y de la actividad de las fuerzas de autodefensa campesina son, por supuesto, un tema que merece mención aparte. Para más información sobre él, véase entre otros: Degregori, Escobal, Marticorena 1992, Degregori 1996A, TAPIA 1995, Jiménez 2009, PietraszczyK 2008 i PietraszcZyK-SĘKowsKa 2011. 


\section{Bibliografía}

Ansión 1987 - J. Ansión, Desde el Rincón de los Muertos. Pensamiento mítico en Ayacucho, Lima 1987.

Ansión 1989 - J. Ansión (editor), Pishtacos. De verdugos a sacaojos, Lima 1989.

Ansión, Sifuentes 1989 (1986) - J. Ansión, E. Sifuentes, La imagen popular de la violencia, a través de los relatos de degolladores, en: J. Ansión (coord.), Pishtacos. De verdugos a sacaojos, Lima 1989, pp.61-105.

Berg 1986 - R. Berg, Sendero Luminoso and the Peasantry of Andahuaylas, "Journal of Interamerican Studies and World Affairs", vol. 28, n. 4, 1986, pp.165-196.

Calvo Pérez 2009 - J. Calvo Pérez, Nuevo Diccionario, Español Quechual Quechua-Español, Lima 2009.

COMISEDH 2012 - Comisión de Derechos Humanos, Los Muertos de Ayacucho. Violencia y sitios de entierro clandestinos, Lima 2012.

Coronel 1996 - J. Coronel, Violencia política y respuestas campesinas en Huanta, en: C. I. Degregori (coord.), Las rondas campesinas y la derrota de Sendero Luminoso, Lima 1996, pp.29-116.

Coronel, LoAYza 1992 - J. Coronel, C. Loayza, Violencia política: formas de respuesta comunera, en: C. I. Degregori, J. Escobal, B. Marticorena (coords.), Perú: el problema agrario en debate, SEPIA IV, Lima 1992, pp.509-537.

CRISTÓBAL 2003 - J. Cristóbal (ed.), Uchuraccay o el rostro de la barbarie, Lima 2003.

CVR 2003 - Comisión de la Verdad y Reconciliación, Informe Final de CVR, Lima 2003.

CVR 2008 - Comisión de la Verdad y Reconciliación, Hatun Willakuy. Versión abreviada del Informe Final de la Comisión de la Verdad y Reconciliación, Lima 2008.

Degregori 1985 - C. I. Degregori, Sendero Luminoso. I. Los hondos y mortales desencuentros, II Sendero Luminoso: lucha armada y utopía autoritaria, Documento de Trabajo, n. 4 y 6, Lima 1985.

Degregori 1992 - C. I. Degregori, Campesinado andino y violencia, en: C. I. Degregori, J. Escobal, B. Marticorena (coords.), Perú: el problema agrario en debate, SEPIA IV, Lima 1992, pp.413-439.

Degregori $1996 \mathrm{a}$ - C. I. Degregori (editor), Las rondas campesinas y la derrota de Sendero Luminoso, Lima 1996. 
Degregori 1996b - C. I. Degregori, Cosechando tempestades: las rondas campesinas y la derrota de Sendero Luminoso en Ayacucho, en: C. I. Degregori (coord.), Las rondas campesinas y la derrota de Sendero Luminoso, Lima 1996, pp.189-225.

Degregori 2003 - C. I. Degregori (editor), Jamás tan cerca arrometió lo lejos, Lima, 2003.

Degregori 2013 - C. I. Degregori, Qué difícil es ser Dios. El Partido Comunista del Perú - Sendero Luminoso y el conflicto armado interno en el Perú: 1980-1999, Lima 2013.

Degregori 2015 [1987] - C. I. Degregori, Entre los fuegos de Sendero y el ejército: el regreso de los pishtacos, en: Jamás tan cerca arremetió lo lejos. Sendero Luminoso y la violencia política, Obras Escogidas X de Carlos Iván Degregori, Lima 2015, pp.109-113.

Degregori, Escobal, Marticorena 1992 - C. I. Degregori, J. Escobal, B. Marticorena (eds), Perú: el problema agrario en debate, SEPIA IV, Lima 1992.

Del Pino 1992 - P. del Pino, Los campesinos en la guerra. O de cómo la gente comienza a ponerse macho, en: C. I. Degregori, J. Escobal, B. Marticorena (coords.), Perú: el problema agrario en debate, SEPIA IV, Lima 1992, pp.487-508.

Del Pino 1996 - P. del Pino, Tiempos de Guerra y de dioses: Ronderos, evangélicos y senderistas en el valle del río Apurímac, en: C. I. Degregori (coord.), Las rondas campesinas y la derrota de Sendero Luminoso, Lima 1996, pp.117-188.

Del Pino 2003 - P. del Pino, Uchuraccay: memoria y representación de la violencia política en los Andes, en: C. I. Degregori (coord.), Jamás tan cerca arrometió lo lejos, Lima 2003, pp.49-93.

Del Pino 2017 - P. del Pino, En nombre del gobierno. El Perú y Uchuraccay: un siglo de politica campesina, Juliaca 2017.

Dhakal 2011 - S. Dhakal, Political Anthropology and Anthropology of Politics, "Dhaulagiri Journal of Sociology and Anthropology", vol. 5, 2011, pp.217-234.

Flores Galindo, Manrique 1986 - A. Flores Galindo, N. Manrique, Violencia y campesinado, Lima 1986.

GorRiti 1990 - G. Gorriti, Sendero. Historia de la guerra milenaria en el Perú, t. I, Lima 1990.

Granda Oré 1989 - J. Granda Oré, El Nakaq, o la recreación de la conciencia étnica, en: J. Ansión (coord.), Pishtacos. De verdugos a sacaojos, Lima 1989, pp.115-121. 
Guardia Mayorga 1997 - C. Guardia Mayorga, Diccionario kechwa-castellano, castellano-keczwa, Lima 1997.

Guzmán 1988 - A. Guzmán, Reportaje del siglo: Presidente Gonzalo rompe el silencio, "El Diario", 31.07.1988.

Hosoya 2004 - H. Hosoya, La memoria post-colonial: tiempo, espacio y discursos sobre los sucesos de Uchuraccay, Documento de Trabajo n.134, Lima 2004.

Hurtado Meza 2006 - L. Hurtado Meza, Ejército cholificado: reflexiones sobre la apertura del ejército peruano hacia sectores populares, "Iconos. Revista de Ciencias Sociales", n.26, 2006, pp.59-72.

Isbell 1994 - B. J. Isbell, Shining Path and Peasant Responses in Rural Ayacucho, en: D. S. Palmer (coord.), The Shining Path of Peru, New York 1994, pp.77-100.

JimÉNEz 2009 - E. Jiménez, Chungui. Violencia y trazos de memoria, Lima 2009.

JodŁowsKa, MĄKa 2016 - E. Jodłowska, M. Mąka, Pishtaco. Fenomen symbolizacji traumy kulturowej $w$ społecznościach andyjskich, Kraków 2016.

LEWELLEN 2010 - T. Lewellen, Antropologia polityczna. Wprowadzenie, Kraków 2010.

LuKes 2012 (1985) - S. Lukes, Émile Durkheim. Życie i dzieło, trad. E. Klekot, E. Szul-Skjoeldkrona, Warszawa 2012.

MANRIQUe 1989 - N. Manrique, La década de la violencia, "Márgenes 3", nr 5/6, 1989, pp.137-182.

MANRIQUe 2002 - N. Manrique, El tiempo del miedo. La violencia política en el Perú 1980-1996, Lima 2002.

MArshall 2005 - G. Marshall (editor), Stownik socjologii i nauk społecznych, trad. M. Tabin et all, Warszawa 2005.

Ossio, FuenZalida 1983 - J. Ossio, F. Fuenzalida, La comunidad de Uchuraccay y la región iquichana, en: M. Vargas Llosa (coord.), Informe de la Comisión Investigadora de los Sucesos de Uchuraccay, Lima 1983, pp. 43-82.

Palmer 1994 - D. S. Palmer (editor), The Shining Path of Peru, New York 1994.

Pietraszczyk 2008 - J. Pietraszczyk, Peruwiańskie Komitety Samoobrony w poszukiwaniu nowej roli społecznej, en: M. Kania, A. Kaganiec-Kamieńska (coords.), Doświadczenie demokracji w Ameryce Łacińskiej, Kraków 2008, pp.75-88.

PietraszczyK-SęKOwska 2011 - J. Pietraszczyk-Sękowska, Peruwiańskie sity samoobrony chtopskiej. Od konfliktu zbrojnego do transformacji 
pokojowej (tesis de doctorado sustentada en la UAM en Poznan en 2011).

Portocarrero, Valentín, Yrigoyen 1991 - G. Portocarrero, I. Valentín, S. Yrigoyen, Sacaojos. Crisis social y fantasmas coloniales, Lima 1991.

Portocarrero 1998 - G. Portocarrero, Razones de sangre. Aproximaciones a la violencia política, Lima 1998.

PoSERn-ZielińsKi 2005 - A. Posern-Zieliński, Między indygenizmem a indianizmem. Andyjscy Indianie na drodze do etnorozwoju, Poznań 2005.

Posern-ZIELIŃSKI 2008 - A. Posern-Zieliński, Trudne początki ruchu indiańskiego w Peru, en: M. Kania, A. Kaganiec-Kamieńska (coords.), Doświadczenie demokracji w Ameryce Łacińskiej, Kraków, pp.123138.

Ramos 2010 - G. Ramos, Death and Conversion in the Andes. Lima and Cusco, 1532-1670, Indiana 2010.

Rojas-Perez 2017 - I. Rojas-Perez, Mourning Remains. State Atrocity, Exhumations, and Governing the Disappeared in Peru's Postwar Andes, Stanford 2017.

Rosales-Miranda 2013 - C. Rosales-Miranda, Liturgias con sangre, Lima 2013

SAlCEDo 2013 - J. M. Salcedo, Las tumbas de Uchuraccay: Treinta años después, Iquitos 2013.

StARn 1992 - O. Starn, Antropología andina, “andinismo” y Sendero Luminoso, "Allpanchis", n. 39, 1992, pp.15-71.

Stelmach 2010 - M. Stelmach, Peruwiańskie Sity Zbrojne w procesie transformacji demokratycznej en A. Walaszek, A. Giera (coords.), Transformacje w Ameryce Łacińskiej, Kraków 2011, pp. 51-63.

STERn 1999 - J. Steve (editor), Los senderos insólitos del Perú. Guerra y sociedad 1980-1995, Lima 1999.

ŚniadecKa-KotarsKa 2006 - M. Śniadecka-Kotarska, Być kobieta w Peru, Warszawa 2006.

ŚNIADECKA-KotARSKa 2011 - M. Śniadecka-Kotarska, Kontekst społeczno-polityczny wizyty Jana Pawta II w Peru, en: T. Szyszka (coord.), Jan Paweł II w Peru, Warszawa 2011, pp. 45-71.

TAMAYO 2003 - A. M. Tamayo, ANFASEP y la lucha por la memoria de sus desaparecidos (1983-2000), en: C. I. Degregori (coord.), Jamás tan cerca arremetió lo lejos. Memoria y violencia política en el Perú, Lima 2003, pp.95-134.

TAPIA 1995 - C. Tapia, Autodefensa armada del campesinado, Lima 1995.

TAPIA 1997 - C. Tapia, Las Fuerzas Armadas y Sendero Luminoso. Dos estrategias y un final. Lima 1997. 
Thomas 2001 - V. L. Thomas, Trup. Od biologii do antropologii, trad. K. Kocjan, Warszawa 2001.

Vergara 2009 - A. Vergara, La memoria de la barbarie en imágenes, una introducción, en: E. Jiménez (coord.) Chungui. Violencia y trazos de memoria, Lima 2009, pp.37-67.

Vergara 2013 - A. Vergara, Nakaq: una historia de miedo, en: R. Ayala Huaytalla (coord.), Entre la región y la nación. Nuevas aproximaciones a la historia ayacuchana y peruana, Lima 2013.

Vergara, Ferrúa 1989 [1987] - A. Vergara, F. Ferrúa, Ayacucho: de nuevo los degolladores, en: J. Ansión (coord.), Pishtacos. De verdugos a sacaojos, Lima 1989.

Weismantel 2016 [2003] - M. Weismantel, Cholas y pishtacos. Relatos de raza y sexo en los Andes, trad. C. Gnecco, Lima 2016.

\section{Summary \\ Argentinos, bestias, chaqwa y pishtacos. \\ The experience of terror, cruelty and death in the collective consciousness of Andean villagers during the internal conflict in Peru}

The problem of internal conflict in Peru is a popular research topic that has been analyzed from various scientific perspectives by both domestic and foreign researchers for almost four decades. In addition to the dominant historical and political approaches (mainly focused on structural features of war and its impact on the current shape of the state and society) as well as the anthropological ones (primarily devoted to socio-cultural sources and following reveals of the problem), a significant place is also occupied by the studies of violence, taken up by various disciplines. Application of this perspective is, however, an exceptionally complex task, since, as in the lens, it concentrates systems of links between phenomena and actors, whose figures cannot be clearly outlined. It is particularly evident in relation to forms, scale and perception of terror in the Andes. The article aims at looking for the answer to the question what was going to be the role of the title "terror, cruelty and death" in the military activities in the Peruvian province and how they ultimately influenced collective consciousness of Andean villagers and their attitudes in conflict. Therefore, the analysis concerns, first of all, forms and goals of violence in the Andes and the ways in which serranos visualized them, and then, reactions of the latter to the war experience of dehumanization, death and destruction.

Keywords: internal conflict, terror, death, collective consciousness, indigenous population, the central-southern Andes, Peru 


\section{Streszczenie}

Argentinos, bestias, chaqwa y pishtacos.

Doświadczenia terroru, okrucieństwa i śmierci w świadomości zbiorowej serranos w okresie konfliktu wewnętrznego w Peru

Problematyka konfliktu wewnętrznego w Peru stanowi popularny temat badawczy analizowany z różnych perspektyw naukowych tak przez badaczy krajowych, jak i zagranicznych już od niemal czterech dekad. Poza dominującym w tym zakresie ujęciem historycznym i politologicznym (skupionych głównie na strukturalnych uwarunkowaniach konfliktu oraz jego wpływie na bieżący kształt państwa i społeczeństwa) oraz antropologicznym (poświęconym w pierwszej mierze społeczno-kulturowym źródłom i odsłonom problemu) istotne miejsce zajmują również - podejmowane przez różne dyscypliny - studia nad przemocą. Zastosowanie tej perspektywy jest jednak zadaniem wyjątkowo złożonym, gdyż, jak w soczewce, skupia w sobie systemy powiązań zjawisk i aktorów, których figury nierzadko trudno obrysować. Jest to szczególnie widoczne w odniesieniu do form, skali i percepcji terroru w Andach. Celem artykułu jest poszukiwanie odpowiedzi na pytanie, jaką rolę w działaniach zbrojnych na prowincji pełnić miały tytułowe „terror, okrucieństwo oraz śmierć” i jak ostatecznie wpływały na świadomość zbiorową mieszkańców andyjskich wiosek i ich postawy w konflikcie. Przedmiot analizy stanowią zatem przede wszystkim faktyczne oblicza przemocy w Andach oraz sposoby ich wizualizowania przez serranos, a następnie reakcje tych ostatnich na wojenne doświadczenia dehumanizacji, śmierci i zniszczenia.

Słowa kluczowe: konflikt wewnętrzny, terror, śmierć, świadomość zbiorowa, ludność tubylcza, środkowo-południowe Andy, Peru 